\title{
Selective subsidies, entrepreneurial founders' human capital, and access to $R \& D$ alliances
}

\author{
Luca Grilli* \\ Politecnico di Milano \\ Department of Management, Economics, and Industrial Engineering \\ Via R. Lambruschini 4b, 20156, Milan, Italy.

\begin{abstract}
Samuele Murtinu
University of Groningen

Department of Innovation, Management \& Strategy

Nettelbosje 2 - 9747 AE Groningen, The Netherlands.
\end{abstract}

\begin{abstract}
We investigate if and to what extent the receipt of a "selective" subsidy - a public subsidy awarded through a competitive procedure - helps new technology-based firms (NTBFs) to access R\&D alliances. In particular, we theoretically enquire and empirically analyze which founding team-level characteristics allow NTBFs to: i) get a selective subsidy; and ii) access an R\&D alliance with another firm or a public research organization/university, once the subsidy is awarded. We use a sample of 902 NTBFs that operate in Italy, where industrial policy has never had an explicit and exclusive mandate neither for targeting NTBFs nor for easing their access to R\&D networks. By means of several identification strategies and estimation methods, our results point to the relevance of selective subsidies in facilitating NTBFs to enter R\&D alliances, independently from the objective of the policy measure. Second, founders' technical education figures as a key determinant to get the first selective subsidy. Finally, founders' previous industry-specific work experience allows NTBFs to better exploit the selective subsidy, by positively moderating the impact of the subsidy on the likelihood to establish a corporate $R \& D$ alliance.
\end{abstract}

Keywords: new technology-based firms; selective public subsidies; R\&D alliances; founders' human capital.

JEL codes: H25, H81, L26, M13, M21.

*Corresponding author: luca.grilli@polimi.it; tel.: +39-02-2399-3955. 


\title{
Selective subsidies, entrepreneurial founders' human capital, and access to $R \& D$ alliances
}

\begin{abstract}
We investigate if and to what extent the receipt of a "selective" subsidy - a public subsidy awarded through a competitive procedure - helps new technology-based firms (NTBFs) to access R\&D alliances. In particular, we theoretically enquire and empirically analyze which founding team-level characteristics allow NTBFs to: i) get a selective subsidy; and ii) access an R\&D alliance with another firm or a public research organization/university, once the subsidy is awarded. We use a sample of 902 NTBFs that operate in Italy, where industrial policy has never had an explicit and exclusive mandate neither for targeting NTBFs nor for easing their access to R\&D networks. By means of several identification strategies and estimation methods, our results point to the relevance of selective subsidies in facilitating NTBFs to enter R\&D alliances, independently from the objective of the policy measure. Second, founders' technical education figures as a key determinant to get the first selective subsidy. Finally, founders' previous industry-specific work experience allows NTBFs to better exploit the selective subsidy, by positively moderating the impact of the subsidy on the likelihood to establish a corporate R\&D alliance.
\end{abstract}

Keywords: new technology-based firms; selective public subsidies; R\&D alliances; founders' human capital.

JEL codes: H25, H81, L26, M13, M21. 


\section{Introduction}

New technology-based firms (NTBFs) ${ }^{1}$ play a key role for the future development of societies through the introduction of radical innovations into markets (Timmons and Spinelli, 2003), in the form of new products, processes and organizational innovations (Audretsch, 1995). NTBFs challenge existing technological paradigms (Gans and Stern, 2003), perform a disciplining role toward established industry leaders, open up new market segments and favor the flow of knowledge among (at least apparently) different industries.

However, in many cases, NTBFs are hampered in performing this role, because of difficulties in accessing the complementary assets they need to pursue their growth and innovation strategies (Teece, 1986; Gans and Stern, 2003). To fill this “resource gap”, NTBFs try to establish alliances with third parties (Cooper, 2002; Gans and Stern, 2003; Janowicz-Panjaitan and Noorderhaven, 2008). The formation of an alliance allows NTBFs to exploit the alliance partners' specialized assets (Colombo et al., 2006, 2009), and thus generate economic returns through the enhancement of their own core competences (i.e. distinctive technological capabilities). But, when searching for alliance partners, NTBFs typically face important search costs and high information asymmetries (Teece, 1986) that, on the one side, discourage many good entrepreneurs to look for partners and, on the other side, prevent potential partners to identify the good entrepreneurial projects.

This latter argument calls for a possible government intervention, aimed at supporting embryonic business projects which may turn out to be very valuable for the future social welfare (Lerner, 1999). When the government targets a business project through a "selective" subsidy, ${ }^{2}$ it may exert several beneficial effects to the awarded firm. First, monetary benefits can alleviate possible (relevant) financial constraints, so enabling the firm to realize its potential or - at least - to get close to its optimal level of investment. Second, in order to become successful, entrepreneurs need to 'work long and hard hours and put their new venture ahead of their personal and family life (Hofer 1976; Schein 1987)' (see Douglas and Shepherd, 2000, p. 239), especially at the infancy stages of their newly founded firms. Winning a grant may boost confidence of the proponents on the potential of their

\footnotetext{
${ }^{1}$ We refer to the definition coined by Arthur D. Little (1977) who identifies NTBFs as independently owned businesses that are less than 25 years old and active in high-tech industries. The term NTBF is still widely adopted as in the EU policy arena (since the special issue in Research Policy edited by Storey and Tether in the year 1998, see the report "Funding of New Technology-based Firms by Commercial Banks in Europe" of the European Commission, and several recent OECD reports) as in the scientific community (e.g. Czarnitzki and Delanote, 2015; Grilli, 2014).

${ }^{2}$ We use the definition of "selective” subsidy adopted by Colombo et al. (2011, p. 97): “A selective scheme provides financial support to selected applicants. In this case, applicants compete for receiving a subsidy and their projects are judged by committees formed by experts who are appointed by the government.' Conversely, an automatic scheme gives financial assistance to all applicants who fulfill the specified requirements.
} 
business idea and their own capabilities, and encourage them to fuel more energy and effort in the realization of their project and in the search for collaborative partners (Lerner 2009). Third, selective subsidies may also embody a “stamp of approval” (Lerner, 2002, p. F78) - or “certification effect” which is effective to lower information asymmetries between NTBFs and third parties (Kleer, 2010) and signal to potential alliance partners the high quality of the supported project.

On a priori ground, if the public policy program is efficiently designed, administered and managed, ${ }^{3}$ the governmental action could therefore result into a "win-win-win strategy" for all the main economic agents involved: NTBFs, alliance partners and consumers. As regards NTBFs, the subsidy covers (at least) part of the difference between social and private returns to innovation (Arrow, 1962; Griliches, 1992; Nelson, 1959; Takalo et al., 2013), and thus incentivizes NTBFs to invest in $R \& D$ projects even in presence of high spillovers. As to alliance partners, the collaboration with NTBFs may generate important private benefits as long as the two parties are able to combine their key complementary assets and knowledge resources (Gans et al., 2002; Grant and Baden-Fuller, 2004; Rothaermel, 2001a,b). As to consumers, by easing NTBFs' access to relevant key players either academic or corporate - the provision of selective subsidies may speed-up the technology development process and ultimately increase the dynamic efficiency of the whole economic system.

The beneficial effects of selective subsidies have been explored at both theoretical and empirical levels. Theoretical literature emphasizes how these effects exist and are magnified by the reliability of the governmental body in charge and its capability to select candidates. For example, Takalo and Tanayama (2010) explore on a theoretical basis how "selective" public schemes convey an informative signal to third parties, and prove under a large set of conditions that a certification effect could benefit recipients by alleviating their financing constraints. Starting from different premises and assumptions, the model proposed by Kleer (2010) reaches similar conclusions, by showing that as long as a subsidy embodies a quality signal, this leads to an increase in the number or in the quality of the recipient firm's additional private investments.

The available empirical evidence is thin, and as to NTBFs is totally missing. Meuleman and De Maeseneire (2012), analyzing a sample of 1107 governmentally-supported Belgian firms, find that obtaining an R\&D subsidy enhances the capability of small and medium enterprises (SMEs) to access long-term debt. Similar positive effects on additional funding of grant recipients are also found by Feldman and Kelley (2006) on a sample of applicants to the U.S. Advanced Technology Program at

\footnotetext{
${ }^{3}$ The objective function and efficiency of policy programs could not be taken for granted. Santarelli and Vivarelli (2002) emphasize several threats for social welfare in sustaining firm entry. Moreover, public support may crowd out private R\&D efforts (Wallsten, 2000). Furthermore, politicians may seek to direct subsidies to create political consensus rather than increase social welfare (Lerner, 2002). See Section 2.1 for further discussion.
} 
NIST (National Institute of Standards and Technology). Demeulemeester and Hottenrott (2015) show that being awarded with an R\&D grant leads to lower costs of debt to finance R\&D activities. Howell (2017) finds that a Small Business Innovation Research (SBIR) award doubles the likelihood of the subsidized firm to receive venture capital (and leads to a better commercial and innovative performance). Being primarily focused on the access to investors and creditors, all this literature is tangent to the "crowding-out versus crowding-in" issue of public funding debated since the 1960s (see Zuniga-Vicente et al., 2014 for a recent and updated survey of this vast empirical literature). But it is relatively silent on all other important typologies of third parties - apart from external investors - with whom NTBFs need to establish connections and relationships (e.g. business partners, distribution channels providers, alliance partners). As regards NTBFs, to the best of our knowledge, the beneficial effects embodied by selective subsidies have never been detected directly, but always presumed indirectly, by comparing the economic performance of NTBFs supported by a selective subsidy with that achieved by non-recipients or recipients of other typologies of subsidy (e.g. Colombo et al., 2011, 2013).

In this paper, as first aim, we directly test the existence of a beneficial effect exerted by selective subsidies toward NTBFs, by investigating if selective subsidies ease NTBFs' access to R\&D alliances. While the literature on R\&D collaborations stresses how - for firms in general - the effects of R\&D alliances are highly idiosyncratic and can only be evaluated (ex-post) through a cost-benefit analysis approach (e.g. Grant and Baden-Fuller, 2004; Park and Zhou, 2005), the entrepreneurship literature acknowledges the establishment of an R\&D alliance as an important milestone in the life of an NTBF (Colombo et al., 2009). For this typology of firms, given their limited resources, the capability to collaborate in $\mathrm{R} \& \mathrm{D}$ activities with other established partners, either corporate or academic, is often deemed of crucial importance to leverage their performances (Okamuro et al., 2011).

Secondly, we fill an additional gap in the extant literature by examining if and to what extent founding team-level characteristics have an important role in determining and moderating the relationship between selective subsidies and the formation of R\&D alliances. Specifically, we theorize and empirically investigate whether founding teams' human capital characteristics (in terms of education and work experience) allow NTBFs to obtain a selective subsidy, and to what extent such characteristics moderate NTBFs' ability to exploit the subsidy through the access to R\&D alliances. In doing so, we also investigate for the first time if the moderating role of founders' human capital in this respect depends on the typology of the third party involved in the R\&D alliance, comparing corporate and academic partners. 
Our investigation applies several identification strategies and empirical methods on a representative sample of 902 Italian NTBFs. In the observed time frame (1980-2008), Italian innovation policy lacked any explicit focus on favoring R\&D alliances by NTBFs. Therefore our analysis is able to gauge the effect of selective subsidies on the ability of NTBFs to access R\&D alliances, ruling out any possible tautological relationships in this domain. Our results show that the founders' previous technical education influences the likelihood to receive the first selective subsidy. Then, the receipt of a selective subsidy helps NTBFs to establish an R\&D alliance. While, after the receipt of the grant, founders' previous industry-specific work experience is an important moderator of NTBFs’ ability to establish a corporate R\&D alliance.

The paper proceeds as follows. In Section 2, we introduce the theoretical background and the hypotheses to be tested. Section 3 describes the data and the methodology used for the empirical analysis. In Section 4, we illustrate the econometric results and findings. Finally, Section 5 concludes with implications for policy-making design in the domain of high-tech entrepreneurship and directions for further research.

\section{Research hypotheses}

In this work, we aim to investigate if selective subsidies help NTBFs accessing R\&D alliances and, in doing so, we enquire on the founders' characteristics that most enable NTBFs getting and then exploiting selective subsidies toward R\&D partners. We also hypothesize that the moderating role of the founders' characteristics in the relationship between selective subsidies and R\&D alliances depends on the typology of the third party potentially involved, i.e. a corporate R\&D partner or a public research organization/university.

\subsection{Selective subsidies and $R \& D$ alliances}

There is more than a doubt in the extant literature on whether the governmental intervention in the financing of young firms’ R\&D activities can really solve market failures (e.g. Hall, 1996; Shane, 2009): if the screening process of the governmental body is driven by non-economic motivations e.g. the creation of political consensus (Lerner, 2002) - inefficient recipients might be artificially "kept on the market” (Santarelli and Vivarelli, 2002) and these inefficient firms might crowd-out more efficient firms. As a matter of fact, public officials and nominated committees might have less information on promising technologies and cutting-edge technological trajectories than private managers and scientists enrolled in private firms (Farrell, 1987; Datta-Chaudhuri, 1990; Le Grand, 1991; Goolsbee, 1998). 
Nonetheless, if procedures to allocate governmental subsidies are well-administered, there are a number of reasons to argue that subsidies may help NTBFs get access to R\&D alliances. First, the inflow of monetary resources relaxes NTBFs' (perceived) financial constraints. This makes possible for entrepreneurs - who typically have limited human resource slack (Paeleman and Vanacker, 2012) - to use their time in the search for partners rather than in the quest for external financing. Second, subsidies enable entrepreneurs to scale up the size of their R\&D project(s), thereby making the recipient firms more attractive partners for alliances. ${ }^{4}$

In principle, selective subsidies can also exert a "certification effect" which makes it easier for NTBFs to obtain additional resources from third parties (Lerner, 1999, 2002; Narayanan et al., 2000; Takalo and Tanayama, 2010). As claimed by Meuleman and De Maeseneire (2012: pp. 581-582): 'this certification effect builds on the assumption that the government's assessments are independent, educated and technically sophisticated [...] Government specialists may have sizeable insight in which technologies and companies are most promising.' The thin - and often indirect - empirical evidence on the issue generally brings support to this presumption (Lerner, 1999, 2002; Colombo et al., 2011, 2013; Grilli and Murtinu, 2012; Feldman and Kelley, 2006; Meuleman and De Maeseneire, 2012).

Due to the lack of reputation of NTBFs, the receipt of a public subsidy - after a fierce competition with other entrepreneurial firms and after a positive assessment by a panel of experts nominated by the public authority - should give to the awarded NTBF a legitimacy to the market which lowers information asymmetries toward third parties (Kleer, 2010), including potential alliance partners (Feldman and Kelley, 2006). Moreover, the certification effect provided by selective subsidies should be stronger when information asymmetries are very high, as in the case of basic research (Demeulemeester and Hottenrott, 2015), technology prototyping phase (Howell, 2017), high-tech industries (Lerner, 1999) and early-stage companies (Colombo et al., 2013; Demeulemeester and Hottenrott, 2015; Howell, 2017).

In our study, we focus on R\&D alliances, also called technology partnerships or collaborative innovation networks (Hagedoorn et al., 2000; Hagedoorn, 2002) - which are by far the most diffused in high-tech industries (Hagedoorn and Narula, 1996). By the means of R\&D alliances, NTBFs can increase their value through a series of activities linked to knowledge creation and development: from exploitation of complementary know-how of partner firms (Kogut, 1988; Das and Teng, 2000) to incremental learning (Narula and Dunning, 1998), technological upgrading (Mathews, 2002) and

\footnotetext{
${ }^{4}$ We are indebted to an anonymous reviewer for this suggestion.
} 
absorptive capacity enhancement (Cohen and Levinthal, 1989), passing through simple (but significant) gains in economies of scale in R\&D operations (Kleinknecht and Reijnen, 1992).

Of course, $R \& D$ alliances also entail costs and risks for NTBFs, especially in terms of appropriability hazards related to the distinctive technological competencies possessed by NTBFs. But, besides the presence of several contingencies and nuances (e.g. Colombo et al., 2009; de Jong and Freel, 2010), R\&D alliances have been found on average to positively impact NTBFs' performance on a wide spectrum of measures, including total factor productivity (Colombo et al., 2009), innovation (Baum et al., 2000; Thorgren et al., 2012; Parida et al., 2012), internationalization rates (Fontes and Coombs, 2007), and different measures of firm growth (Stam and Wennberg, 2009). Thus, R\&D alliances are generally considered a prominent goal for NTBFs (Okamuro et al., 2011; Rothaermel, 2002).

Grounding on the above reasoning, and adopting the view of an effective public policy, we therefore posit the following hypothesis:

H1: NTBFs that receive a selective subsidy are more likely to establish an $R \& D$ alliance.

\subsection{Technology-related human capital}

\subsubsection{Human capital as a determinant of NTBFs' access to selective subsidies}

From the point of view of policy makers, selective subsidies should be granted to NTBFs' projects that potentially generate high social returns but whose private returns are diluted due to spillovers or who fail to raise funding due to capital market imperfections (Kleer, 2010; Peneder, 2008). This is the typical scenario faced by many NTBFs in the early stages after their inception. At foundation, NTBFs allegedly possess novel ideas for innovative products or services, due to the strong technical background of their entrepreneurial teams (Colombo and Grilli, 2005; Hsu, 2008). But, such teams often do not possess key managerial skills, resources and capabilities to commercially exploit their business ideas (Gans and Stern, 2003; Teece, 1986). These deficiencies may reduce the interest of financiers and investors, and consequently make more real the risk that innovative firms and novel valid technologies might not come to light.

If the literature is unanimous in identifying the technological competencies possessed by the founding team as the primary asset of an NTBF (Cooper and Bruno, 1977, Andersson and Xiao, 2016), a necessary (but not sufficient) condition for a selective subsidy to be effective is to primarily target those NTBFs characterized by a strong technological core. Even though this condition does not reassure about the absence of a picking-the-winner strategy or a deadweight effect of the policy 
measure (Santarelli and Vivarelli, 2002), the empirical evidence (e.g. Cantner and Kösters, 2012) highlights that R\&D subsidies are allocated to NTBFs with more innovative/novel ideas and whose entrepreneurial teams include academics. To this extent, individuals endowed with technical education should have a better understanding of technology and innovation dynamics (Barker and Mueller, 2002). Thus, a higher level of founders' technical education should be positively related to a higher technical capability of the focal NTBF and consequently to its ability to develop technically deserving projects. Accordingly, we expect that selective subsidies primarily flow toward NTBFs established by founders who are endowed with a relatively strong technological background, as testified by their educational attainments. Therefore we posit the following hypothesis:

H2: Founding teams of NTBFs endowed with a higher level of technical education are more likely to receive a selective subsidy.

Founders' prior work experience, especially when it has been gained in the same industry in which the focal NTBF operates, is a key feature of entrepreneurs' human capital (Cooper and Bruno, 1977; Colombo and Grilli, 2005, Andersson and Xiao, 2016). NTBFs' performance is found to be extensively impacted by the distinctive capabilities possessed by the entrepreneurs, and particularly by the founders' industry-specific work experience (Colombo and Grilli, 2005). Industry-specific skilled individuals - everything else being equal - are better capable to recognize business opportunities (e.g. Marvel, 2013; Shepherd and DeTienne, 2005; Shane, 2000), and exploit them (Ganotakis, 2012). This is due to a superior non-acquirable knowledge of technologies and markets, which is even more valuable the more turbulent and riskier are the industries (Eisenhardt and Martin, 2000), as typically are the R\&D-intensive ones.

But this argument does not lead to conclude that selective public subsidies flow primarily towards NTBFs founded by entrepreneurs with a high level of industry-specific work experience, at least for two reasons. First, founders with high levels of industry-specific work experience may be less in need of public support, due to the greater amount of personal financial resources at their disposal (due to the wealth effect of human capital, see Colombo and Grilli, 2005) and to the more favorable access to alternative financing sources (Gimmon and Levie, 2010). Second, since applications for selective subsidies typically entail high opportunity costs in terms of time and resources, and these opportunity costs are reasonably increasing with the capabilities of NTBFs' founders, valuable projects may selfselect out (Takalo et al., 2013). Since opposite forces are at work we do not pose any explicit hypothesis on the direction of the impact of founders' industry-specific work experience on NTBFs' likelihood to access public selective subsidies. 


\subsubsection{Human capital as a moderator in the relationship between selective subsidies and NTBFs' access to $R \& D$ alliances}

The technological knowledge of the founding team can be not only an important driver to get the selective subsidy, but also an important moderator in the relationship between the receipt of a selective subsidy and the access to R\&D alliances. In other words, once an NTBF is facilitated in the search for R\&D partners by being awarded with a selective subsidy, specific founders' human capital characteristics might magnify the impact of the policy intervention in this domain. This moderating role could be rooted in two main theoretical arguments.

First, the founders' technological human capital influences the appropriability hazards arising from an $R \& D$ alliance and may shape the incentives to enter into a technological relationship. In this respect, the moderating impact might depend on the typology of the R\&D alliance partner. In particular, a higher level of technical education means a higher absorptive capacity (Cohen and Levinthal, 1990) and ability to both learn from the partner's technology and internalize the positive externalities arising from the collaboration.

If appropriability hazards might be a concern in deciding whether to establish an R\&D business relationship with another profit-oriented firm - given the (mutual) fear of being expropriated of some key knowledge assets - these concerns are totally absent if the counterpart is a public research organization, which often has technology transfer as one of the main missions to accomplish. Consequently, founding teams with a higher level of technical education might have greater chances to activate R\&D collaborations with universities and other public research organizations, without facing the risk to expose themselves to the typical appropriability hazard problems which may arise in inter-firm alliances (Oxley, 1997).

Second, the nature of human capital shapes the boundaries of an individual's acquaintances and considerably contributes to determine her/his social network both in links' formation and intensity (Lincoln and Miller, 1979). This applies in general (Girard et al., 2015), but it also importantly characterizes entrepreneurial dynamics (Low and McMillian, 1988; Anderson and Miller, 2003). Accordingly, a higher level of technical education (e.g. a $\mathrm{PhD}$ in engineering or physics) increases the span of individuals involved in $R \& D$ activities with whom a focal entrepreneur may get acquainted, and this should - ceteris paribus - raise the possibilities for the focal NTBF to start collaborating on an R\&D activity with third parties (Eesley et al., 2014). The fact that this technical background has been gained at university should prominently increase the probability to start collaborating with universities and public research organizations. Thus, we posit the following hypothesis: 
H3: Technical education of founding teams positively moderates NTBFs' ability to exploit the selective subsidy through an $R \& D$ alliance with an university or a public research organization.

Following the literature on networks and entrepreneurship (e.g. Aldrich and Zimmer, 1986), the founders' industry-specific work experience represents a key asset for the social ties and connections on which the NTBF may rely upon (e.g. Dubini and Aldrich, 1991; Brüderl and Preisendörfer, 1998). Several studies on alliances have investigated the relationship between trust and partners' selection using a firm-level approach (e.g. Gulati, 1995; Li et al., 2008). What these studies highlight is that firms select their partners not only because of the resources held by such partners, but also by assessing the risk of appropriability hazards faced and the level of protection such firms can exert on their own valuable resources. Gulati (1999) considers social factors that influence the extent to which firms engage in alliances over time.

Adhering to his perspective, Mosey and Wright (2007) show that entrepreneurs' prior business experience impacts on the ability to develop ties and industry networks, and attract industry partners. Describing the formation of whaling expeditions in New England during the 1800s, Helfat and Peteraf (2003) put forward the same idea. Thus, long-lasting prior work experience should be a good indicator of founders' available network resources, which are due to repeated transactions within the market. These network resources might enhance the trust of potential alliance partners - especially other firms - toward the focal NTBF, lowering appropriability hazards, and thus increase the likelihood to access external resources, e.g. through an R\&D alliance.

These arguments are also coherent with the view of Eisenhardt and Schoonhoven (1996): individuals with a higher endowment of work experience should be better known in their industry, and so it should be relatively easier for potential alliance partners to evaluate the risk of opportunism of NTBFs' founders and vice versa. Being the circle of acquaintances importantly formed by business contacts, highly experienced individuals in the industry should also have more chances to build a reputation in the industry and acquire those skills needed to manage more efficiently the appropriability hazards arising from the R\&D collaboration. On the basis of these arguments, we posit the following hypothesis:

H4: Industry-specific work experience of founding teams positively moderates NTBFs' ability to exploit the selective subsidy through an $R \& D$ alliance with a corporate partner.

\section{Data and Methodology}




\subsection{National policy schemes toward NTBFs in Italy}

Given the expectedly positive impact of $R \& D$ alliances on small and young high-tech firms, central governments have increasingly attempted to directly foster R\&D alliances involving NTBFs. Different policy schemes have been launched at different latitudes to meet this goal and exogenously induce a more cooperative attitude in and towards this typology of firms. ${ }^{5}$

Whether the evidence about the effects of these policy-directed $R \& D$ alliances is thinner and surely more nuanced than the one referring to the endogenously-determined R\&D alliances (see Okamuro and Nishimura, 2015 for a recent exploration of the Japanese case), the Italian context here analyzed allows to rule out any possible tautology in the investigation of the relationship between selective subsidies and NTBFs' access to R\&D alliances (see infra). In fact, our empirical test-bed will be represented by Italian NTBFs observed during the 1980-2008 time window. During this period, Italy has been characterized by very few support schemes at central government-level directed toward NTBFs: 'most of the measures implemented by the Italian Government were directed to all firms or in some circumstances were limited to small and medium enterprises whose NTBFs represent only a subset' (Grilli and Murtinu, 2012, p. 101).

In this study, we focus on all those central government schemes based on selective and competitive procedures that Italian NTBFs had accessed during the observation period. These procedures entailed a screening activity of entrepreneurial projects performed by technical committees composed by (corporate and academic) experts who were appointed by the central government institution in charge of the corresponding policy measure. Projects were evaluated and ranked on the basis of specific criteria known ex-ante by the applicants. Generally, merit criteria included the scientific-technical and/or the financial feasibility of the proposals (e.g. Law 902/1976; Law 46/1982, Law 95/1995) and/or an assessment of the impact of the business idea on specific social welfare measures such as the capacity to generate new employment (e.g. Law 902/1976, Law 488/1992) or environmental sustainability (e.g. Law 488/1992).

The (main) objectives of these "selective" subsidies relate to the support of R\&D investments (e.g. Law 1089/1968) but they also include other dimensions. Topical examples include the "Fondo Speciale Rotativo per l’Innovazione Tecnologica” (Special Fund for Technological Innovation), a fund that was set-up by the Law 46/1982 to convert pre-competitive R\&D efforts in technological

\footnotetext{
${ }^{5}$ Among the most recent policy initiatives, see e.g. the Industrial Cluster Project (ICP) in Japan (Nishimura and Okamuro, 2011); all Flanders' innovation policy emphasis between 2002 and 2008 on awarding R\&D collaborations by small and medium-sized firms reported in Hottenrott and Lopes-Bento (2014); or the Spanish PROFIT Program described in Santàmaria et al. (2010).
} 
applications; the Law 236/1993 which sustained firms in the advanced job training activities of their workforce; and the Law 488/1992 that aimed at sustaining a large spectrum of investment typologies, ranging from new facilities building to machineries and software purchase.

Many of these investigated measures also include preferential access and specific merit criteria for firms located in economically depressed areas, and in particular in the South of Italy (Law 44/1986; Law 64/1986; Law 488/1992). As anticipated above, none of these measures had an explicit focus to induce the establishment of alliances among NTBFs or between NTBFs and other typologies of (corporate or academic) partners, or foresee any explicit merit criteria in this respect. Thus, the institutional environment we analyze represents a well-suited test-bed to investigate whether selective subsidies - regardless their different objectives - can increase the likelihood for NTBFs to access R\&D alliances.

\subsection{Data}

In this paper, we exploit detailed information on the variables of interest for a sample of 902 Italian NTBFs, which have been founded between 1980 and 2008. Strictly adhering to the standard definition of NTBFs (see footnote 1), all these firms are observed until their age is equal to or less than 25 years old (they exit the dataset when they become older than 25 years). Sample firms were independent at founding date (i.e. they were not controlled by another business organization even though other organizations may have held minority shareholdings), are considered NTBFs until they remain independent (in case of liquidation or merger/acquisition events only pre-event information is used), and operate in high-tech industries.

The sample is drawn from the RITA (Research on Entrepreneurship in Advanced Technologies) database, developed at Politecnico di Milano. The database is the most detailed and comprehensive source of data on Italian NTBFs available today (for a detailed description of the database, see Grilli et al., 2014 and the Appendix there contained). ${ }^{6}$ The RITA database was used in many previous works on policy (Colombo et al., 2013), economics (Colombo et al., 2011), management and entrepreneurship (Colombo et al., 2009) scientific journals. As to December $31^{\text {st }}$ 2012, the total number of NTBFs included in the RITA database is 1,979 .

The directory was created by the RITA Observatory research team at Politecnico di Milano at the end of 1999 and was extended through the inclusion of new firms and the update of old information

\footnotetext{
${ }^{6}$ In the domain of Italian NTBFs, the use of official statistics for the construction of the firms' population is problematic because of two main reasons: i) most self-employed individuals are salaried workers with atypical employment contracts, and cannot be distinguished from a newly created firm's owner-managers; and ii) the impossibility to isolate firms that were incorporated as subsidiaries of other firms. Thus, it is important to stress that due to the criteria used for the construction of the RITA database, our sample does not include lifestyle firms and firms that are created purely for taxsaving reasons.
} 
through four different survey waves centered in the years 2000, 2002, 2004, and 2008. The surveys were based on a questionnaire that was sent to the contact person of the target firms (i.e. firm owner or manager) either by fax or e-mail. Answers to the questions were checked for internal coherence by trained research assistants and were compared with information published in firms' annual reports, websites and popular press. In several cases, phone or face-to-face follow-up interviews were made with firms' owner-managers. This final step provided an opportunity to collect missing data and ensured that the data were reliable.

Our sample of 902 NTBFs is composed of all those NTBFs of which we had a complete information set on the variables of interest for this work: i) the human capital characteristics of the firms' founders; ii) the full history of the subsidies received by NTBFs from national governmental bodies; and iii) the full history of R\&D alliances established by NTBFs. Conversely to the majority of other survey-based empirical settings in the innovation and entrepreneurship literature, the RITA dataset and our sample include firms that eventually exited markets due to bankruptcy or lost their independence because of merger/acquisition events (source: Union of Italian Chambers of Commerce). The inclusion in the empirical analysis of those NTBFs that experienced such events (145 firms) through the use of pre-event information should keep at minimum the risk of a possible survivorship bias in the investigated dynamics.

The industrial distribution of NTBFs in our sample is as follows: the highest number of companies (56.5\%) operates in the software and internet industries (e.g. e-commerce, internet service provider, software house and data mining), the $23.2 \%$ operates in the ICT manufacturing industries (e.g. electronic equipment and devices, telecommunications equipment), while the $17.1 \%$ operates in other manufacturing industries (i.e. aerospace, biotechnology, chemical, pharmaceuticals). Finally, the $3.2 \%$ of our sample operates in other service industries, such as environmental services and R\&D engineering.

As to the geographical distribution, $44 \%$ of sample firms are located in the North-West of Italy, while $21 \%$ are in the North-East, $19 \%$ in the Centre of Italy and 16\% are located in the South of the country. In order to ensure that the regional and industrial distributions of our sample firms are representative of the population of Italian NTBFs from which the sample is extracted, we perform two chi-square tests. These latter show that there are no statistically significant differences between the distributions of the 902 sample firms across Italian regions $\left(\chi^{2}(17)=21.33\right)$ and industries $\left(\chi^{2}(2)=3.54\right)$ and the corresponding distributions of the RITA population from which the sample is drawn.

\subsection{The specification of the econometric models}


In analyzing the relationship between the receipt of selective subsidies and R\&D alliance formation, we firstly need to consider that these two events could happen independently of each other, i.e. R\&D alliances could be established by either subsidized or non-subsidized NTBFs. Secondly, selective subsidies are a potentially endogenous variable. The traditional approach to the above setting is to use a two-stage least squares (2SLS) estimator with (at least) one instrumental variable (IV) for the key potentially endogenous explanatory variable. However, in our sample both the outcome variable and the endogenous variable are binary, and thus the use of an IV probit model is likely to produce inconsistent estimates (Wooldridge, 2010). Hence, we use three estimation methodologies to indicate a causal effect: the maximum likelihood (ML) recursive bivariate probit estimator (Greene, 1998), the standard two-stage least squares (2SLS) estimator, and the special regressor method described in Dong and Lewbel (2015).

\subsubsection{ML recursive bivariate probit estimator}

The ML recursive bivariate probit model (Greene, 1998) consistently estimates models where the outcome variable is binary, and the potentially endogenous covariate of interest is binary and it is likely to be jointly determined with the outcome variable.

Specifically, we estimate the following recursive bivariate probit model:

$$
\begin{aligned}
& \text { R\&D Alliance }_{i}=f_{1}\left(\text { Selective Subsidy } y_{i}, X_{i}\right) ; \\
& \text { Selective Subsidy } y_{i}=f_{2}\left(X_{i}, Z_{i}\right) .
\end{aligned}
$$

The model is a recursive simultaneous equations model that consists of two probit equations which are estimated simultaneously to control for the potential unobserved heterogeneity between the two equations (Bhattacharya et al., 2006). $R \& D$ Alliance is a binary variable that takes value one if the NTBF $i$ has ever established an R\&D alliance during its life. Selective Subsidy is a dummy variable which equals one if the NTBF $i$ has been awarded with a public selective subsidy before having (eventually) established an R\&D alliance. ${ }^{7}$ The fact that the eventual subsidy award happens before the $R \& D$ alliance partially mitigates endogeneity and reverse causality issues. The vector $X_{i}$ contains a set of founders' human capital variables - which may impact both the firm's likelihood of an R\&D alliance and the likelihood to get a selective subsidy - and the control variables. Specifically, Technical Education is the average number of years of technical post-graduate education gained by the founding team (from bachelor to $\mathrm{PhD}$ degrees in science, technology, mathematics and

\footnotetext{
${ }^{7}$ Few NTBFs (13) received selective subsidies after their first R\&D alliance. According to our definition of Selective Subsidy, for these firms the variable equals zero. Note that excluding such firms from our estimation leave our findings unaltered.
} 
engineering fields, including physics, biology, chemistry, medicine, pharmaceutics, and computer science); Industry-Specific Work Experience measures the average number of years of professional experience gained by founders in the same industry of their NTBF, before founding this latter; Economic Education is the average number of years of founders' economic-managerial post-graduate education; Management Experience equals one for NTBFs having in their founding team at least one serial entrepreneur or a founder with previous experience as a professional manager in a firm with more than 250 employees; LogFounders controls for the size of the founding team, as measured by the natural logarithm of the number of founders. A set of industry dummies are inserted in the vector of controls.

The vector $Z_{i}$ includes the exclusion restrictions. Even though one instrument is sufficient to estimate the above recursive simultaneous equations model, we estimate an over-identified model to properly test the validity of the instruments we chose. In particular, we focus on two instrumental variables sourced from the World Values Survey (WVS) ${ }^{8}$ and related to the willingness of entrepreneurs to apply for selective subsidies. ${ }^{9}$ Specifically, we rely on two region-level variables: Control versus Fate and Libertarian.

Control versus Fate refers to the following survey question: 'Some people feel they have completely free choice and control over their lives, while other people feel that what they do has no real effect on what happens to them. Please use this scale where 1 means "no choice at all” and 10 means “a great deal of choice” to indicate how much freedom of choice and control you feel you have

\footnotetext{
${ }^{8}$ The WVS started in 1981 and now is conducted by a network of social scientists around the world. WVS data relate to human values, motivations and beliefs, and come from nationally representative surveys which include around the $90 \%$ of the world's population. A common questionnaire - translated in native language - is used in each country to ensure cross-country comparisons and avoid country-specific biases. Country-level stratified random samples of respondents are drawn from people who are at least 18 years old with no upper age limit in most countries. The minimum country-level sample is 1000. For more details see: http://www.worldvaluessurvey.org/wvs.jsp.

9 Initially, our first choice as instrument was the yearly expenditures for final consumption of Italian public administrations (PAs) at regional (NUTS 2) level (source: Italian National Institute of Statistics). This variable should be correlated to the likelihood that an NTBF receives a selective subsidy, while it should not be correlated with the likelihood that an NTBF accesses an R\&D alliance. The theoretical motivation is rooted on the fact that selective subsidies managed by the central government and regional expenditures of PAs are typically substitutes, at least in the Italian context (e.g. Cooke, 2001). As argued by Cassette and Paty (2010), the amount of national public sector budgets and regional ones are often inversely related, especially after the increasing decentralization policy trends starting in the late 1980s within most EU Member States. So, the higher are the expenses of the PAs in a given region, the lower should be the supply of selective subsidies by the national government in that geographical context, and thus the likelihood that NTBFs in that region will be awarded with a selective subsidy should be lower, ceteris paribus. While the probability to establish an R\&D alliance or not for an NTBF should remain unaffected, one may object that this is unlikely for R\&D alliances with universities. In fact, central government expenditures do affect (to some degree) the State university budgets, and in turn, these latter may affect the willingness/capabilities of universities to accomplish their third mission by reducing their alliance activity with third parties (including NTBFs). If this concern is valid from a theoretical point of view, the empirical evidence on our sample of NTBFs shows indeed a weak correlation $(-0.12)$ between the potential instrument and NTBFs' access to R\&D alliances with universities. However, since this correlation is negative (and therefore in line with the above theoretical argument), we prefer not to use this variable as an instrument in our empirical analysis. Nonetheless, it is worthwhile to note that our main findings are unaltered with its eventual inclusion.
} 
over the way your life turns out.' Grounding on the seminal distinction between individualistic and collectivistic societies (Hofstede, 1980; 2001), internal locus of control is a more prevalent psychological trait in individualistic cultures (Mueller and Thomas, 2001), where entrepreneurs are more likely to consider themselves as self-sufficient (Pinillos and Reyes, 2011) and "emotionally independent” from the collectivity (Hofstede, 1980). Accordingly, entrepreneurs embedded in such high internal locus of control regions should be less likely to quest for State external aid to realize their projects. Therefore, we expect a negative correlation between Control versus Fate and the likelihood to get a selective subsidy, that is, the higher is the belief to have control over her/his life, and the lower will be the incentive of the entrepreneur to rely on selective subsidies.

Libertarian refers instead to the following survey question: 'I'm going to describe various types of political systems and ask what you think about each as a way of governing this country. For each one, would you say it is a very good, fairly good, fairly bad or very bad way of governing this country?'. We consider survey respondents who express their agreement on the sub-item 'Having a strong leader who does not have to bother with parliament and elections' on a 1-4 scale where 1 means “very good” and 4 means “very bad”. As highlighted by Miller (1974), the level of trust of economic agents in the State is also a function of the outcome coming by the frequent interactions among them. People who strongly believe in the democratic institutional apparatus of the State are those who think that the public interests have been sufficiently well-administered and are less incline to invoke any authoritarian non-accountable leader to change the situation. In such institutional contexts there is more confidence that civil servants will put forward the public interest rather than pursue private objectives, and that public money disbursement will be more transparent and efficient (Arin et al., 2011).

In this respect, we claim that the Italian regions where the perceived need for any strong leader is lower are the regions where entrepreneurs are more likely to apply for selective subsidies - because entrepreneurs can expect fair selection procedures put forward by the technical committees appointed by the central government (Samphantharak and Malesky, 2008). ${ }^{10}$ Accordingly, we expect a positive correlation between Libertarian and the likelihood to get a selective subsidy, that is, the higher (lower) is the trust in the region on the democratic apparatus (an authoritarian non-accountable leader) and the higher will be the likelihood to get a selective subsidy.

Table I provides a detailed description of all the variables.

\footnotetext{
${ }^{10}$ The argument that more transparent and democratic institutions lead to a more active participation of citizens to the economic life of a society (and vice versa) dates back to the seminal treatise of Alexis De Tocqueville (1835), Democracy in America.
} 
[Table I about here]

Equation (1) is estimated also considering different typologies of $R \& D$ alliance as dependent variables. Specifically, Corporate $R \& D$ Alliance is a binary variable that takes value one if the NTBF $i$ has ever established during its life an $\mathrm{R} \& \mathrm{D}$ alliance with another firm. University $R \& D$ Alliance is a binary variable that takes value one if the NTBF $i$ has ever established during its life an R\&D alliance with an university or a public research organization. ${ }^{11}$

\subsubsection{Standard 2SLS estimator}

Even though Blundell and Powell (2003), Lewbel (2000) and Terza et al. (2008) showed that standard 2SLS estimators are not well-tailored for estimating binary outcome models, scholars frequently use them (e.g. Forman and Zeebroeck, 2012). Angrist and Pischke (2008) suggest how it is difficult to ascertain the best estimator in the above setting. They individuate in linear probability models estimated through a 2SLS estimator a sort of "lesser evil”, but of course these models should be corroborated by alternative estimators (see also Angrist, 2001), as we in fact do in our study.

In the application of this method, as exogenous shocks that influence the likelihood to get a selective subsidy, we still use the two above explained WVS variables: Control versus Fate and Libertarian. The estimation is composed of two steps, as represented by the equations (2) and (1) respectively. In the first step we estimate the probability that the entrepreneurial company gets the selective subsidy (dependent variable: Selective Subsidy), and the regressors are all the variables included in the vector $X_{i}$ together with the two above exclusion restrictions (Control versus Fate and Libertarian). Even though Selective Subsidy is a dichotomous variable we use a linear regression to avoid the “forbidden regression” bias (Angrist and Pischke, 2008, p. 190).

\subsection{3 “Special regressor” method}

Another approach to estimate our binary outcome model is the use of the "special regressor" method (see Dong and Lewbel, 2015). The starting point for the use of the special regressor method builds on the characteristics of the two above explained methods. Specifically, a 2SLS approach hinges on OLS estimation for both steps, and the properties of 2SLS were originally derived in the

\footnotetext{
${ }^{11}$ We built the two variables (Corporate $R \& D$ Alliance and University $R \& D$ Alliance) through a competing risk logic with exclusive absorbing states (Cameron and Trivedi, 2005). More specifically, a firm can be in three alternative states of nature: i) the firm established a corporate R\&D alliance, ii) the firm established an university R\&D alliance, or iii) the firm did not establish any R\&D alliance. The state of nature iii) acts as counterfactual of both states of nature i) and ii). If a firm established a corporate R\&D alliance at year $t$ and an $R \& D$ alliance with an academic partner at year $t+1$, this firm is only included in the state of nature i). Conversely, if a firm established an university R\&D alliance at year $t$ and an R\&D alliance with a corporate partner at year $t+1$, this firm is only included in the state of nature ii). This operationalization strategy that considers only the first type of an R\&D alliance established by NTBFs allows us to obtain the two cleanest counterfactuals for our samples of corporate and university R\&D alliances.
} 
presence of continuous endogenous independent variables and continuous dependent variables. When the 2SLS approach is applied to a non-linear setting, where endogenous independent variables and/or dependent variables are dichotomous, such approach may lead to biased estimates (Blundell and Powell 2003; Terza et al. 2008).

The ML recursive bivariate probit model (Greene, 1998) may be a solution to the above 2SLSrelated shortcomings, that is, a ML recursive bivariate probit model consistently estimates models where the outcome variable is binary, and the potentially endogenous covariate of interest is binary. However, to estimate a ML recursive bivariate probit model, it is necessary to assume a full parametric joint distribution of the error terms in the two steps (Bhattacharya et al., 2006). Dong and Lewbel (2015) propose an estimation method that still belongs to an IV framework, but that aims at overcoming the above empirical challenges (see also Lewbel et al., 2012).

Specifically, the special regressor method allows to estimate econometric models where i) the dependent variable is dichotomous, ii) one or more independent variables are endogenous, and iii) residuals are heteroskedastic (of unknown functional form, whose second and higher moments can depend on either other regressors or instruments for the assumed endogenous regressors) and not independent from independent variables. In other words, the special regressor method has the same properties of a 2SLS estimator (i.e. no necessity to assume a fully parametric joint distribution of the error terms; allowance for unknown forms of heteroskedasticity), but it is consistent when it is applied to a non-linear setting, where the endogenous independent variables and the dependent variables are dichotomous.

Strictly following Lewbel et al. (2012, p. 821) and Dong and Lewbel (2015, p. 89), plus a series of recent applications (e.g. Whelan and McGuiness, 2017), the special regressor $\left(V_{i}\right)$ method consists of four different steps: (1) estimate a linear regression where $V_{i}$ is a function of the vector of regressors $X_{i}$ (including endogenous regressors: in our case Selective Subsidy $y_{i}$ ) and instruments $Z_{i}$; (2) get the residuals $\left(\widehat{u}_{\imath}\right)$ from (1) and compute their density function, i.e. $f\left(\widehat{u}_{\imath}\right)$; (3) build the new dependent variable, $\widehat{T}_{l}=\left[R \& D\right.$ Alliance $\left._{i}-I\left(V_{i} \geq 0\right)\right] / f\left(\widehat{u_{l}}\right)$, where $I$ is an indicator function that equals one if the $\operatorname{argument} V_{i}$ is greater or equal than zero (i.e. the special regressor must be demeaned); 4) run a 2SLS regression where $\widehat{T}_{l}$ is the dependent variable, $X_{i}$ and $V_{i}$ are the regressors, and using $Z_{i}$ as instruments.

So, the intuition behind this method remains the same as the one of a standard IV method, where the special regressor (which has not to be intended as an instrument, see Section 4.2) allows a reformulation of the dependent variable (steps 2 and 3 above). This transformation enables the estimation of a 2SLS regression (step 4), which leads to properly bounded estimated coefficients (Wooldridge, 2010) in contexts where both the outcome and the independent endogenous variables 
are binary (see Dong and Lewbel, 2015 for formal proofs and details). One of the requirements of the special regressor method is the existence of one exogenous variable that is conditionally independent of (and additive to) the residual - whichever the number of endogenous independent variables.

Given the relatively high flexibility in the choice of the special regressor, we resort to an exogenous historical-based variable: the regional average bank branch density in 1936, as measured by the values of bank branches per inhabitant (Guiso et al., 2004). Guiso et al. (2004) show how the reorganization of the banking system in 1936 - in terms of rules and regulations put in place at that time - still greatly influences nowadays the entrepreneurial orientation of an area. Accordingly, we posit that this variable should improve the chances for entrepreneurs to access external resources, and in particular R\&D alliances, but, at the same time, be so rooted in the past to be conditionally independent from all more recent unobserved heterogeneity possibly affecting our dependent variable, i.e. $R \& D$ Alliance.

Said that, we checked whether the assumptions of the method hold in our data. First, as shown in Figure I, we verified that the errors $\left(\widehat{u_{l}}\right)$ are far from being Normally distributed and, therefore, a nonparametric Kernel density function was chosen to estimate $f\left(\widehat{u_{l}}\right)$ in the above step 2.

[Figure I about here]

Second, we checked whether the distribution of the special regressor has a sufficiently large support. Dong and Lewbel (2015, p. 96) claim that the standard deviation of the special regressor must be larger than that of the predicted value of the 2SLS in the above step 4. In our data, there is large support because the former is 75.1285 while the latter is 0.0202 . Third, we also checked through a locally weighted regression framework the monotonicity of the relationship between the special regressor $\left(V_{i}\right)$ and $R \& D$ Alliance (results available upon request). All these checks ensure that the variable we chose as special regressor satisfies the required technical assumptions of the procedure developed by Dong and Lewbel (2015).

\subsection{Descriptive statistics and correlation matrix}

In Table II, we show the descriptive statistics of the explanatory variables and exclusion restrictions. In our sample, $10.42 \%$ of NTBFs has received a selective subsidy (before the eventual access to an R\&D alliance). On average, founders show a higher level of technical rather than economic-managerial education (1.9 vs. 0.3 years). Founding teams are composed on average by three entrepreneurs whose average industry-specific work experience is four years. On average, only one NTBF out of five includes (at least) one serial entrepreneur or a founder with a previous experience as professional manager in a firm with more than 250 employees. 


\section{[Table II about here]}

In Table III, we provide the correlation matrix including the dependent variables and the main regressors of our econometric analysis. No issues of multicollinearity seem to be present among the independent variables; variance inflation factor (VIF) tests were also run and confirmed the absence of multicollinearity concerns: the mean VIF is 1.10, and the maximum VIF is 1.15, which are pretty lower than the commonly used threshold of 10. As a first and preliminary insight on our hypotheses, there is a positive and significant correlation between the receipt of a selective subsidy and the likelihood to establish an R\&D alliance and there is a positive and significant correlation between the founding teams' technical education and the likelihood to be awarded with a selective subsidy.

[Table III about here]

Finally, Table IV reports the number of NTBFs that were granted a selective subsidy and those that established an R\&D alliance. The NTBFs that were granted a selective subsidy (before the eventual access to an R\&D alliance) were 94 (10.42\% of the sample). NTBFs that had ever established an R\&D alliance were 395 (43.79\%). The unconditional probability of establishing an R\&D alliance was higher for NTBFs that had previously obtained a public selective subsidy (56 NTBFs out of 94: 59.6\%) than those that did not (339 out of 808: 41.96\%). NTBFs are more prone to corporate R\&D alliances (316 NTBFs out of 821: 38.49\%) than to university R\&D alliances (175 NTBFs out of 681: 25.7\%). Again both typologies of alliance appear more likely when NTBFs previously obtained a selective subsidy: the unconditional probability of establishing an alliance with another firm is $47.9 \%$ (35 NTBFs out of 73) for ex-ante subsidized NTBFs and 37.6\% (281 NTBFs out of 748) for nonsubsidized firms; while, the unconditional probability of establishing an alliance with an university is $49.3 \%$ (37 NTBFs out of 75) for ex-ante subsidized NTBFs and 22.77\% (138 NTBFs out of 606) for non-subsidized firms.

[Table IV about here]

\section{The empirical analysis}

\subsection{Results on hypotheses 1 and 2}

ML recursive bivariate probit results are shown in Table V. In Panels A and B, the dependent variables are Selective Subsidy and $R \& D$ Alliance, respectively. In columns II and III, we split R\&D alliances according to the type of partner, and the dependent variables are Corporate R\&D Alliance and University $R \& D$ Alliance, respectively.

[Table V about here] 
In line with hypothesis 1 , the likelihood of establishing an R\&D alliance significantly increases if the NTBF has been previously awarded with a public selective subsidy. The coefficient of the variable Selective Subsidy is always positive and statistically significant - at the 5\% confidence level in the first two columns, and at the $1 \%$ in the last column.

To obtain an immediate and overall glimpse of the economic magnitude of the investigated effects we also perform the following simulation exercises. We take as benchmark the "mean" NTBF of our sample with no selective subsidy. This NTBF has a probability to establish an R\&D alliance of 42\%, a probability to establish a corporate $R \& D$ alliance of $39 \%$, and a probability to establish an university R\&D alliance of $19 \%$. These probabilities raise to $82 \%, 80 \%$ and $69 \%$, respectively if the status of this NTBF switches from "non-subsidized with a selective subsidy" to "subsidized with a selective subsidy”.

Interestingly, both types of founders' education (technical and economic-managerial) are found to positively and significantly impact the probability of an NTBF to establish an R\&D alliance (the only exception is the lack of significance of Economic Education in the third column). Furthermore, in line with those studies suggesting a positive nexus between a firm's slack of organizational resources and its activism in terms of strategic alliance formation (e.g. Marino et al., 2008), we find that the likelihood to establish an R\&D alliance is positively affected by the size of the founding team. Finally, neither founders' industry-specific work experience nor management experience are found to drive the likelihood to establish an R\&D alliance.

In Panel A we find that founders' technical education positively affects the likelihood to receive a selective subsidy. In column I, where the model is estimated on the full sample of 902 NTBFs, the coefficient of technical education is positive and statistically significant at the $5 \%$ confidence level. This confirms our hypothesis 2 . The coefficient loses some statistical significance in columns II and III, where the number of observations is reduced.

As above, to get an estimate of the economic magnitude of the correlation between founders' technical education and the likelihood to receive a selective subsidy we perform a simulation exercise. Still taking as benchmark the "mean" NTBF of our sample, this firm has a probability of being awarded with a selective subsidy of $12 \%$. An increase in the technical education endowment of the founding team from the mean level (i.e. 1.9 years) to the $90^{\circ}$ percentile of the variable (i.e. 5 years) increases the probability to get a selective subsidy to $15 \%$. Then, also in line with our theoretical reasoning, the other technology-related founders' human capital characteristics - specifically Industry-Specific Work Experience - are not found to be associated with the NTBF's likelihood to get a selective subsidy. As to our instruments, Control versus Fate and Libertarian are always strongly 
statistically significant, and the sign of their coefficients are, as expected, negative for the former and positive for the latter.

Standard 2SLS results are shown in Table VI. The values of F tests on excluded instruments (equal to 14.00 in column I, 11.76 in column II, 8.88 in column III, always statistically significant at the 1\% confidence level) show that our exclusions restrictions are reliable. Further, the Anderson LM statistics (equal to 27.481 in column I, 23.173 in column II, 17.591 in column III, always statistically significant at the 1\% confidence level) always reject the null hypothesis of weak identification. Finally, Sargan tests (equal to 1.730 in column I, 1.195 in column II, 1.805 in column III) do not reject the null hypothesis on the validity of our two exclusion restrictions at conventional confidence levels. Estimation results are fully in line - in both magnitude and statistical significance - with those shown in Table $\mathrm{V}$ and are no further commented. ${ }^{12}$

\section{[Table VI about here]}

Finally, the results of the "special regressor" method are shown in Table VII. They confirm the positive association between the receipt of a selective subsidy and the likelihood to access an R\&D alliance, with a partial exception of University $R \& D$ alliances where there is a slight loss in statistical significance.

[Table VII about here]

\subsection{Robustness checks}

First, even if the Sargan tests at the bottom of Table VI reassure us about the validity of our two instruments, and the F tests on excluded instruments and the Anderson LM statistics prove the reliability of our identification strategy, we further test that our exclusion restrictions are satisfied.

\footnotetext{
${ }^{12}$ As a further robustness check, we enlarge our instrument set with a new variable which captures more directly the institutional rules of the subsidy allocation followed by the Italian policy maker. As reported in Section 3.1, the policy maker showed an institutionalized preference for least developed regions (in particular, the South of Italy). If, in principle, the NTBF's location in a less developed region may act as exclusion restriction, this variable could also be (a) negatively correlated to the chances of an NTBF to establish a corporate R\&D alliance, i.e. because of the hurdles to reach potential partners and of a possible scarce appeal exerted towards partners, due to its disadvantaged location; or even (b) positively correlated to the chances of an NTBF to establish an R\&D alliance with a southern university, which in this case would play a sort of supplementary role given the absence of viable networking possibilities for a nearby located NTBF. These arguments theoretically question the validity of the above variable as an instrument. Therefore, we decided to proceed as follows. We first tested whether the NTBF's location in a less developed region is a valid instrument from an empirical perspective. Specifically, the correlation with the dependent variable Corporate $R \& D$ Alliance is around +0.06 and it is not statistically significant, while the correlation with the dependent variable University $R \& D$ Alliance is around +0.12 and it is statistically significant at $1 \%$ confidence level. As to the correlation with the dummy Selective Subsidy, it is statistically significant (at $1 \%$ confidence level) and it is around +0.17 . Thus, NTBF's location in a less developed region is not a valid instrument for university R\&D alliances, while it is a candidate for corporate R\&D alliances. Then, we reestimated our models on corporate R\&D alliances (those on university R\&D alliances are not reliable by construction) using the above variable as an additional instrument, and the results - available upon request from the authors - are still very similar to those already presented.
} 
For instance, there might be an omitted variable (e.g. general trust towards other people) that is correlated with both the instruments and the dependent variable. To this extent, we re-ran our main models in Table V and Table VI by adding General Trust as an additional regressor in both steps.

Specifically, we refer to the following region-level World Values Survey (WVS) question "Generally speaking, would you say that most people can be trusted or that you need to be very careful in dealing with people?”, where a value equal to 1 means “Most people can be trusted” and a value equal to 2 means "Need to be very careful" (for an empirical validation of the above WVS trust question with experimental measures of trust, see Johnson and Mislin, 2012; for other empirical applications using the above WVS question to measure trust, see e.g. La Porta et al., 1997; Knack and Keefer, 1997; Tabellini, 2010; Zak and Knack, 2001). As shown in Tables A1 and A2 (in the Appendix), General Trust is never statistically significant in second-step regressions in both ML recursive bivariate probit and IV-2SLS estimations. It is only statistically significant (at $10 \%$ level) in the first-step of both ML recursive bivariate probit and IV-2SLS estimations for corporate alliances. More importantly, the statistical significance (and magnitude) of our instruments is not impacted at all, and all our findings are unaltered by the introduction of this variable in our model specification. ${ }^{13}$

Second, to further investigate the validity of our instruments, we adopt a control function approach (Heckman, 1976; Heckman and Robb, 1985) and estimate Two-Stage Residual Inclusion (2SRI) regressions (Basu et al., 2017). While in standard 2SLS regressions both steps are estimated by means of OLS regressions (and this could lead to imprecise estimates, as explained in Section 3.3.3), 2SRI regressions could represent (beside the "special regressor" of Section 3.3.3) another appropriate IV estimation method when the dependent variables in the first- and/or second-steps are binary, especially when there are no strong priors about the joint distribution of the error terms in the two steps (Blundell and Powell 2003, 2004; Terza et al. 2008).

Namely, we follow these steps. First, we estimate a first-stage probit model where the dependent variable is Selective Subsidy. Second, we estimate the residual of this probit model. Third, we estimate a probit model where the dependent variable is $R \& D$ Alliance (Corporate $R \& D$ Alliance and University $R \& D$ Alliance, respectively). In this model, we included the first-step residuals as an additional regressor. Further, we added the two instruments as additional regressors. It is worth noting that we use bootstrap to consistently estimate the standard errors in the second step (for more details see Efron, 1981; Efron and Tibshirani, 1986; Gonçalves and White, 2005). As shown in Table A3 (in

\footnotetext{
${ }^{13}$ In unreported regressions, we also used alternative WVS measures of trust based on the extent to which individuals rely on others in setting their goals. Results are fully in line with those shown here below, and are available upon request from the authors.
} 
the Appendix), the two instruments are not statistically significant in the second-step, thus reassuring us about the validity of the two instruments.

Finally, we test whether the special regressor has actually not the statistical properties of an instrument (as explained in Section 3.3.3). To such an extent, we re-ran our ML recursive bivariate probit and 2SLS regressions in Tables V and VI by adding the special regressor as an additional instrument in the first-step, and the special regressor is never statistically significant, as shown by its coefficient (and standard error) in the first-step of the ML recursive bivariate probit estimation, and the $t$ statistic associated to its coefficient in the first-step of the 2SLS estimation (see Tables A4 and A5 in the Appendix).

\subsection{Results on hypotheses 3 and 4}

Having tested the robustness of the positive relationship between receipt of selective subsidies and NTBFs' access to R\&D alliance by the means of the three methods above exposed, in this section we test hypotheses 3 and 4 through the use of probit models. Specifically, we estimate equation (1) augmented with two additional regressors: the interaction terms between Selective Subsidy and the two technology-related human capital variables Technical Education and Industry-specific work experience, respectively.

In this setting, we cannot use the above methodologies because of the typical bias associated with the fact that the covariates in equations (1) and (2) are not the same (the so-called "covariate ambivalence” problem, see Angrist and Pischke, 2008, p. 189). As it is clear, the above interaction terms cannot be included in the estimation of equation (2) because Selective Subsidy is the dependent variable of that equation. But given the binary nature of the dependent variable, the effects of these interaction terms have been explored over the full range of covariate values through graphical techniques (see on this issue, Ai and Norton, 2003; Hoetker, 2007).

Figure II reveals that Technical Education does not positively moderate the likelihood for an NTBF to establish an R\&D alliance with an university after being awarded with a selective subsidy. Conversely, the moderation (and the associated marginal effect of the interacted variable shown in Figure III) is negative suggesting that the founders' technical education and the knowledge potentially accessible through collaborations with universities and public research organizations are (at least to some extent) substitutes rather than complements for NTBFs once they are subsidized. Thus, hypothesis 3 is not supported.

[Figure II about here]

[Figure III about here] 
Instead, Figure IV shows a positive moderation of the variable Industry-Specific work experience on the relationship between selective subsidies and the likelihood to establish corporate $R \& D$ alliances. As reported in Figure V, the marginal effect of the interaction term becomes positive and statistically significant at $5 \%$ level for NTBFs whose founders have at least seven years (i.e. the $75^{\text {th }}$ percentile in our sample) of industry-specific professional experience. Thus, hypothesis 4 is supported.

[Figure IV about here]

[Figure V about here]

To check the reliability of these results, we implement an identification strategy aimed at overcoming the aforementioned "covariate ambivalence” problem. Namely, we use an IV probit setting and estimate two regressions where the dependent variables are University $R \& D$ Alliance and Corporate $R \& D$ Alliance, respectively. The (supposedly) endogenous independent variable in the second-step of these regressions (Selective Subsidy and its interaction terms with Technical Education and Industry-specific work experience) are instrumented with the predicted value of Selective Subsidy (by means of a linear probability model) and its interactions with Technical Education and Industryspecific work experience. Thus, in the first stage we have three instruments (the predicted value of Selective Subsidy, the predicted value of Selective Subsidy*Technical Education and the predicted value of Selective Subsidy*Industry-specific work experience) for the three potentially endogenous independent variables in the second-step (for a similar approach, see Colombo et al., 2013).

The three instruments are found to be very powerful in explaining "their associated first-step dependent variable”. In fact, the goodness of instruments was verified through ad-hoc first-stage regressions for each instrument that reveal that each one is positively and significantly correlated (at $1 \%$ significance level) with the corresponding variable to be instrumented. ${ }^{14}$ As reported in Table A6 (in the Appendix), the results of the IV probit models confirm our previous findings and (do not) support H4 (H3).

\section{Concluding remarks}

\subsection{Summary of results}

\footnotetext{
${ }^{14}$ Specifically, Predicted Selective Subsidy is strongly correlated to Selective Subsidy (coefficients (s.e.) of 0.772 (0.358) and $1.167(0.424)$ in the first stage regressions of the IV probit models on University $R \& D$ Alliance and Corporate R\&D Alliance, respectively); Predicted Selective Subsidy*Technical Education is strongly correlated with Selective Subsidy*Technical Education (coefficients (s.e.) of 1.404 (0.254) and 1.151 (0.309), respectively); and Predicted Selective Subsidy*Industry-Specific Work Experience is strongly correlated with Selective Subsidy*Industry-Specific Work Experience (coefficients (s.e.) of 1.156 (0.336) and 1.166 (0.269), respectively).
} 
In this work, we firstly investigate if selective subsidies - public financial support measures to selected applicants - increase the possibilities of NTBFs to access R\&D alliances, where we distinguish between corporate partners and universities or public research organizations. Secondly, we analyze the role of the founders' human capital in both enabling an NTBF to be awarded with a selective subsidy and moderating the relationship between the reception of the selective subsidy and the establishment of an R\&D alliance.

Our results can be summarized as follows. We found evidence that selective subsidies do help NTBFs establish R\&D alliances, providing support to those empirical studies that showed the effectiveness of selective subsidies, but only indirectly (Colombo et al., 2011, 2013; Grilli and Murtinu, 2012). Here, we identify a possible important channel through which this positive effect unfolds. Moreover, we show that the ability to exploit the subsidy toward third-parties is not uniform and independent from both the typology of the R\&D alliance partner and the characteristics of the awarded NTBFs' founding teams. We show in fact that the enabling role of selective subsidies for NTBFs towards R\&D alliances applies to both corporate and academic partners. Moreover, our results highlight that the human capital characteristics that influence the reception of the subsidy founders' technical education - weakly moderates the relationship between selective subsidies and R\&D alliances. Conversely, the ability to exploit the selective subsidy appears to be significantly enhanced by the founders' level of industry-specific work experience when matching with $R \& D$ corporate partners.

\subsection{Limitations}

This work has some important limitations. First, the nature of our data prevented us to dig further into the detected positive role of selective subsidies in increasing the networking possibilities of NTBFs. Admittedly, our findings are in line and totally compatible with the certification hypothesis of selective subsidies put forward by Lerner (1999, p. 293) but do not prove it and alternative explanations might be at work. Second, the reception of a selective subsidy can interact with other potential market signals the NTBF might activate - such as patenting (Hsu and Ziedonis, 2008) or new product development (Rothaermel, 2002) - which are not explored here. Third, we do not investigate if the selective subsidy eases contacts with other third parties (e.g. venture capitalists) than the ones considered here.

Fourth, while we use three different estimation methodologies and three different instruments that all yield qualitatively similar findings, it is nonetheless debatable whether we are able to uncover a causal relationship between selective subsidies and alliance formation. We suggest that subsidy granting agencies should be more bold and consider ways to start conducting randomized control 
trials that would allow the agencies to learn the (causal) effects of their subsidies. Fifth, we do not have data on the administrative costs of the selective procedures, and which percentage of these costs weights on the taxpayers. Thus, we cannot perform any type of welfare analysis, and in particular we cannot estimate whether the benefits for selectively subsidized companies are greater than the taxpayers' additional taxes. Even though all these dimensions represent limitations of the present study - but also interesting avenues for future research that figure high in our agenda - we believe that our analysis offers interesting implications for policy design in the field of high-tech entrepreneurship.

\subsection{Implications}

The first contribution of this study is to document the positive effect of any selective subsidy towards an NTBF's capability to access R\&D alliances. To the extent that the design and governance of cluster policies involving new technology-based firms might be problematic (see for example Okamuro and Nishimura 2015), this is a good news. In fact our results show that policy makers may by-pass the problem by granting selective subsidies to NTBFs and endogenously leave to the recipient firm the decisions related to alliances. In other words, inducing exogenously "forced marriages" between the parties may be an inferior policy as long as NTBFs supported by selective subsidies are able to find their own way to ally with R\&D partners.

Second, our work emphasizes the role that governments can play not just as mere providers of financial resources to solve potential capital market imperfections, but also as active endorsers of entrepreneurial projects. Given the NTBFs' legitimacy gap in markets (Freeman et al., 1983), this indirect function might be as much as important as the direct financial assistance. NTBFs operate in highly uncertain and turbulent markets and their lack of a track record leads to high information asymmetries in building relationships with third parties (Hsu, 2006).

The fact that our findings are coherent with the view that selective subsidies are effective in reducing these information asymmetries leads also to the identification of specific dimensions of policy intervention which are worth of attention (Grilli, 2014). First of all, the professional status and technical competence of the appointed committees that are called to decide on the subsidy awardees is a key feature of the policy. In fact, the higher is the reputation of such committees, the more effective should be the reduction of these information asymmetries. For the same reason, the level of competition to get the subsidy must be high. To trigger the enabling role of the subsidy, geographically smaller contests do not seem to be the best solution, because of the alleged low number of potential participants. Third, application procedures should not entail cumbersome administrative costs to avoid any potential adverse selection mechanisms in the pool of candidates. 
Our third contribution is the analysis on how the heterogeneity of founding teams' competencies might be beneficial for NTBFs. Technical competencies are only one side of the token. Our study, in line with most of the literature on the field (e.g. Colombo et al., 2014), shows that the experience matured by the founding team in the same industry of the NTBF allows to better exploit the selective subsidy toward R\&D corporate partners. This result confirms that the specific work experience has an extremely relevant role in explaining the performance of firms and economic organizations (Becker, 1975), and it highlights a specific channel through which this dimension proves to be crucial for the business success of NTBFs (Cooper and Bruno, 1977; Romijn and Albaladejo, 2002; Colombo and Grilli, 2005; Grilli et al., 2014).

This finding has also relevant policy implications, since it stresses the importance for governmental agencies when gauging the technological feasibility and quality of entrepreneurial projects to look not only at the founders' technical skills but also at their business-related experience. In fact, our analysis shows that only a combination of the two characteristics maximizes the odds of success of selective subsidies, by easing NTBFs’ access to R\&D alliances.

\section{Acknowledgements}

We thank the Editor, three anonymous reviewers, Niccolò Ghio, participants to the Conference on Collaboration for Innovation (University of Groningen), the EU-SPRI Early Career Researcher Conference "Sowing the seeds of the future: The financing of tomorrow's innovations" (University of Bergamo), the International Conference on the Dynamics of Entrepreneurship (CoDE), and the XXV AiIG Annual Scientific Meeting for helpful comments and suggestions. Responsibility for any errors lies solely with the authors. 


\section{References}

Ai, C., Norton, E.C., 2003. Interaction terms in Logit and Probit models. Economics Letters 80, 123129.

Aldrich, H.E., Zimmer, C., 1986. 'Entrepreneurship through Social Networks’, in H.E. Aldrich (ed.), Population Perspectives on Organizations. Uppsala: Acta Universitatis Upsaliensis, pp. 13-28.

Anderson, A.R., Miller, C.J., 2003. “Class matters”: human and social capital in the entrepreneurial process. Journal of Socio-Economics 32, 17-36.

Andersson, M., Xiao, J., 2016. Acquisitions of start-ups by incumbent businesses A market selection process of "high-quality” entrants?, Research Policy 45, 272-290.

Angrist, J.D., 2001. Estimation of limited dependent variable models with dummy endogenous regressors: Simple strategies for empirical practice. Journal of Business \& Economic Statistics 19, $2-16$.

Angrist, J.D., Pischke, J.S., 2008. Mostly Harmless Econometrics: An Empiricist's Companion. Princeton University Press.

Arin, K.P., Chmelarova, V., Feess, E., Wohlschlegel, A., 2011. Why are corrupt countries less successful in consolidating their budgets? Journal of Public Economics, 95, 521-530.

Arrow, K., 1962. 'Economic welfare and the allocation of resources for invention' in UniversitiesNational Bureau Committee for Economic Research, Committee on Economic Growth of the Social Science Research Council (ed.), The Rate and Direction of Inventive Activity: Economic and Social Factors. Princeton University Press, pp. 609-626.

Arthur D. Little, 1977. New technology-based firms in the United Kingdom and the Federal Republic of Germany. London: Wilton House.

Audretsch, D.B., 1995. Innovation and Industry Evolution. MIT Press, Cambridge MA.

Barker, V.L., Mueller, G.C., 2002. CEO characteristics and firm R\&D spending. Management Science 48, 782-801.

Basu, A., Coe, N., Chapman, C.G., 2017. Comparing 2SLS vs. 2SRI for Binary Outcomes and Binary Exposures (No. w23840). National Bureau of Economic Research.

Baum, J.A.C, Calabrese T., Silverman, B.S., 2000. Don’t go it alone: Alliance network composition and startups’ performances in Canadian biotechnology. Strategic Management Journal 21, 267294.

Becker, G.S., 1975. Human Capital. National Bureau of Economic Research, New York.

Bhattacharya, J., Goldman, D., McCaffrey, D., 2006. Estimating probit models with self-selected treatments. Statistics in Medicine 25, 389-413. 
Blundell, R., Powell, J.L., 2003. Endogeneity in nonparametric and semiparametric regression models. Econometric Society Monographs 36, 312-357.

Blundell, R.W., Powell, J.L., 2004. Endogeneity in semiparametric binary response models. Review of Economic Studies 71, 655-679.

Brüderl J., Preisendörfer, P., 1998. Network support and the success of newly founded business. Small Business Economics 10, 213-225.

Cameron, A.C., Trivedi, P.K., 2005. Microeconometrics. Cambridge University Press, New York.

Cantner, U., Kösters, S., 2012. Picking the winner? Empirical evidence on the targeting of R\&D subsidies to start-ups. Small Business Economics 39, 921-936.

Cassette, A., Paty, S., 2010. Fiscal decentralization and the size of government: a European country empirical analysis. Public Choice 143, 173-189.

Cohen, W.M., Levinthal, D.A., 1989. Innovation and learning: the two faces of R\&D. Economic Journal 99, 569-596.

Cohen, W.M., Levinthal, D.A., 1990. Absorptive capacity: a new perspective on learning and innovation. Administrative Science Quarterly 35, 128-152.

Colombo, M.G., Croce, A., Murtinu, S., 2014. Ownership structure, horizontal agency costs and the performance of high-tech entrepreneurial firms. Small Business Economics 42, 265-282.

Colombo, M.G., Giannangeli, S., Grilli, L., 2013. Public subsidies and the employment growth of high-tech start-ups: assessing the impact of selective and automatic support schemes. Industrial and Corporate Change 22, 1273-1314.

Colombo, M.G., Grilli, L., 2005. Founders' human capital and the growth of new technology-based firms: a competence based view. Research Policy 34, 795-816.

Colombo, M.G., Grilli, L., Murtinu, S., 2011. R\&D subsidies and the performance of high-tech startups. Economics Letters 112, 97-99.

Colombo, M.G., Grilli, L., Murtinu, S., Piscitello, L., Piva, E., 2009. Effects of international R\&D alliances on performance of high-tech start-ups: A longitudinal analysis. Strategic Entrepreneurship Journal 3, 346-368.

Colombo, M.G., Grilli, L. Piva, E., 2006. In search for complementary assets: the determinants of alliance formation of high-tech start-ups. Research Policy 35, 1166-1199.

Cooke, P., 2001. Regional innovation systems, clusters, and the knowledge economy. Industrial and Corporate Change 10, 945-974.

Cooper, A.C., 2002. ‘Networks, alliances, and entrepreneurship’. In Hitt, M. A., Ireland, R. D., Camp, S. M. and Sexton, D. L. (Eds), Strategic Entrepreneurship: Creating a New Mindset. Oxford: Blackwell Publishers, pp. 203-17. 
Cooper, A.C., Bruno, A.V., 1977. Success among high-technology firms. Business Horizons 20, 1622.

Czarnitzki, D., Delanote, J., 2015. R\&D policies for young SMEs: input and output effects. Small Business Economics 45, 465-485.

Das, T.K., Teng, B.S., 2000. A resource-based theory of strategic alliances. Journal of Management 26, 31-61.

Datta-Chaudhuri, M., 1990. Market failure and government failure. Journal of Economic Perspectives 4, 25-39.

de Jong, J.P.J., Freel, M., 2010. Absorptive capacity and the reach of collaboration in high technology small firms. Research Policy 39, 47-54.

De Tocqueville, A., 1835. Democracy in America. Liberty Fund Inc, Indianapolis, U.S.

Demeulemeester S., Hottenrott H., 2015. R\&D subsidies and firms' cost of debt. DICE (Dusseldorf Institute for Competition Economics) Discussion Paper No 201, Dusseldorf (Germany).

Dong, Y., Lewbel, A., 2015. A simple estimator for binary choice models with endogenous regressors. Econometric Reviews 34, 82-105.

Douglas, E., Shepherd, D., 2000. Entrepreneurship as a utility maximizing response. Journal of Business Venturing 15, 231-251.

Dubini, P., Aldrich, H.E., 1991. Personal and extended networks are central to the entrepreneurial process. Journal of Business Venturing 6, 305-313.

Eesley, C.E., Hsu, D.H., Roberts, E.B., 2014. The contingent effects of top management teams on venture performance: Aligning founding team composition with innovation strategy and commercialization environment. Strategic Management Journal 35, 1798-1817.

Efron, B., 1981. Nonparametric estimates of standard error: the jackknife, the bootstrap and other methods. Biometrika 68, 589-599.

Efron, B., Tibshirani, R., 1986. Bootstrap methods for standard errors, confidence intervals, and other measures of statistical accuracy. Statistical Science 1, 54-75.

Eisenhardt, K.M., Martin, J.A., 2000. Dynamic capabilities: what are they? Strategic Management Journal 21, 1105-1121.

Eisenhardt, K.M., Schoonhoven, C.B., 1996. Resource-Based view of strategic alliance formation: Strategic and social effects in entrepreneurial firms. Organization Science 7, 136-150.

European Commission, 2000. Funding of New Technology-based Firms by Commercial Banks in Europe. Brussels, ISBN 92-828-9731-1.

Farrell, J., 1987. Information and the Coase theorem. Journal of Economic Perspectives 1, 113-129. 
Feldman, M.P., Kelley, M.R., 2006. The ex ante assessment of knowledge spillovers: Government R\&D policy, economic incentives and private firm behavior. Research Policy 35, 1509-1521.

Fontes, M., Coombs, R., 1997. The coincidence of technology and market objectives in the internationalisation of new technology-based firms. International Small Business Journal 15, 1435.

Forman, C., Zeebroeck, N.V., 2012. From wires to partners: How the Internet has fostered R\&D collaborations within firms. Management Science, 58, 1549-1568.

Freeman, J., Carroll, G.R., Hannan, M.T., 1983. The liability of newness: Age dependency in organizational death rates. American Sociological Review 48, 692-710.

Ganotakis, P., 2012. Founders' human capital and the performance of UK new technology based firms. Small Business Economics 39, 495-515.

Gans, J.S., Hsu, D.H., Stern, S., 2002. When does start-up innovation spur the gale of creative destruction? RAND Journal of Economics 33, 571-586.

Gans, J.S., Stern, S., 2003. The product market and the market for “ideas": commercialization strategies for technology entrepreneurs. Research Policy 32, 333-350.

Gimmon, E., Levie, J., 2010. Founder's human capital, external investment, and the survival of new high-technology ventures. Research Policy 39, 1214-1226.

Girard, Y., Florian, H., Schunk, D., 2015. How individual characteristics shape the structure of social networks. Journal of Economic Behavior \& Organization 115, 197-216.

Gonçalves, S., \& White, H., 2005. Bootstrap standard error estimates for linear regression. Journal of the American Statistical Association, 100, 970-979.

Goolsbee, A., 1998. Does government R\&D policy mainly benefit scientists and engineers? American Economic Review 88, 298-302.

Grant, R.M., Baden-Fuller, C., 2004. A knowledge accessing theory of strategic alliances. Journal of Management Studies 41, 61-84.

Greene, W.H., 1998. Gender economics courses in liberal arts colleges: Further results. Journal of Economic Education 29, 291-300.

Griliches, Z., 1992. The search for R\&D spillovers. Scandinavian Journal of Economics 94, 29-47.

Grilli, L., 2014. High-Tech entrepreneurship in Europe: A heuristic firm growth model and three “(Un-)easy Pieces” for policy-making. Industry and Innovation 21, 267-284.

Grilli, L., Jensen, P.H., Murtinu, S., 2014. The imprinting of founders' human capital on entrepreneurial venture growth: Evidence from new technology-based firms. Melbourne Institute Working Paper No. 14/13, http://www.findanexpert.unimelb.edu.au/display/publication196986; SSRN Working Paper Series, http://ssrn.com/abstract=2245324. 
Grilli, L., Murtinu, S., 2012. Do public subsidies affect the performance of new technology-based firms? The importance of evaluation schemes and agency goals. Prometheus 30, 97-111.

Guiso, L., Sapienza, P., Zingales, L., 2004. Does local financial development matter? Quarterly Journal of Economics 119, 929-969.

Gulati, R., 1995. Social structure and alliance formation patterns: A longitudinal analysis. Administrative Science Quarterly 40, 619-652.

Gulati, R., 1999. Network location and learning: the influence of network resources and firm capabilities on alliance formation. Strategic Management Journal 20, 397-420.

Hagedoorn, J., 2002. Inter-firm R\&D partnerships: an overview of major trends and patterns since 1960. Research Policy 31, 477-492.

Hagedoorn, J., Link, A.N., Vonortas, N.S., 2000. Research partnerships. Research Policy 29, 567586.

Hagedoorn, J., Narula, R., 1996. Choosing modes of governance for strategic technology partnering: international and sectoral differences. Journal of International Business Studies 27, 265-284.

Hall, B.H., 1996. 'The private and social returns to research and development' in B.L.R. Smith and C.E. Barheld (ed.), Technology, R\&D, and the Economy. Washington DC: Brookings Institution and American Enterprise Institute, pp. 140-162.

Heckman, J.J., 1976. Simultaneous equation models with both continuous and discrete endogenous variables with and without structural shift in the equations. Studies in Nonlinear Estimation, Ballinger.

Heckman, J.J., Robb, R., 1985. Alternative methods for evaluating the impact of interventions: An overview. Journal of Econometrics 30, 239-267.

Helfat, C.E., Peteraf, M.A., 2003. The dynamic resource-based view: Capability lifecycles. Strategic Management Journal 24, 997-1010.

Hoetker, G., 2007. The use of Logit and Probit models in strategic management research: Critical issues. Strategic Management Journal 28, 331-343.

Hofer, C.W., 1976. Research on strategic planning: A survey of past studies and suggestions for future efforts. Journal of Economics and Business 38, 261-287.

Hofstede, G., 1980. Culture’s Consequences: International Differences in Work-related Values. Beverly Hills, CA: Sage Publications.

Hofstede, G., 2001. Culture’s Consequences (2nd ed.). Thousand Oaks: Sage Publications.

Hottenrott, H., Lopes-Bento, C., 2014. (International) R\&D collaboration and SMEs: The effectiveness of targeted public R\&D support schemes. Research Policy 43, 1055-1066. 
Howell, S.T., 2017. Financing innovation: evidence from R\&D grants. American Economic Review 107, 1136-1164.

Hsu, D.H., 2006. Venture capitalists and cooperative start-up commercialization strategy. Management Science 52, 204-219.

Hsu, D.H., 2008. 'Technology-Based Entrepreneurship' in N.J. Hoboken (ed.), Handbook of Technology and Innovation Management. Wiley Publishing, pp. 367-388.

Hsu, D.H., Ziedonis, R.H., 2008. Patents as quality signals for entrepreneurial ventures. Academy of Management Proceedings 1, 1-6.

Janowicz-Panjaitan, M., Noorderhaven, N.G., 2008. Formal and informal interorganizational learning within strategic alliances. Research Policy 37, 1337-1355.

Johnson, N.D., Mislin, A., 2012. How much should we trust the World Values Survey trust question? Economics Letters 116, 210-212.

Kleer, R., 2010. Government R\&D subsidies as a signal for private investors. Research Policy 39, 1361-1374.

Kleinknecht, A., Reijnen, J.O.N., 1992. Why do firms cooperate on R\&D? An empirical study. Research Policy 21, 347-360.

Knack, S., Keefer, P., 1999. Does social capital have an economic payoff? A cross-country investigation. Quarterly Journal of Economics 112, 1251-1288.

Kogut, B., 1988. Joint ventures: Theoretical and empirical perspectives. Strategic Management Journal 9, 319-332.

La Porta, R., Lopez de Silanes, F., Shleifer, A., Vishny, R., 1997. Trust in large organizations. American Economic Review 87, 333-338.

Le Grand, J., 1991. The theory of government failure. British Journal of Political Science 21, 423442.

Lerner, J., 1999. The government as venture capitalist: the long-run impact of the SBIR program. Journal of Business 72, 285-318.

Lerner, J., 2002. When bureaucrats meet entrepreneurs: the design of effective public venture capital programmes. Economic Journal 112, F73-F84.

Lerner, J., 2009. Boulevard of Broken Dreams: why Public Efforts to Boost Entrepreneurship and Venture Capital have Failed--and What to Do about It. Princeton University Press.

Lewbel, A., 2000. Semiparametric qualitative response model estimation with unknown heteroscedasticity or instrumental variables. Journal of Econometrics 97, 145-177.

Lewbel, A., Dong Y., Yang, T.T., 2012. Comparing features of convenient estimators for binary choice models with endogenous regressors. Canadian Journal of Economics 45, 809-829. 
Li, D., Eden, L., Hitt, M.A., Ireland, R.D., 2008. Friends, acquaintances, or strangers? Partner selection in R\&D alliances. Academy of Management Journal 51, 315-334.

Lincoln, J.R, Miller J., 1979. Work and friendship ties in organisations: a comparative analysis of relational networks. Administrative Science Quarterly 24, 181-199.

Low, M.B., MacMillian I.C., 1988. Entrepreneurship: past research and future challenges. Journal of Management 14, 139-161.

Marino, L.D., Lohrke, F.T., Hill, J.S., Weaver, K.M., Tambunan, T., 2008. Environmental shocks and SME alliance formation intentions in an emerging economy: evidence from the Asian financial crisis in Indonesia. Entrepreneurship Theory \& Practice 32, 157-183.

Marvel, M.R., 2013. Human capital and search-based discovery: a study of high-tech entrepreneurship. Entrepreneurship Theory \& Practice 37, 403-419.

Mathews, J.A., 2002. The origins and dynamics of Taiwan’s R\&D consortia. Research Policy 31, 633-651.

Meuleman, M., De Maeseneire, W., 2012. Do R\&D subsidies affect SMEs' access to external financing? Research Policy 41, 580-591.

Miller, A.H., 1974. Political issues and trust in government: 1964-1970. American Political Science Review 68, 951-972.

Mosey, S., Wright, M., 2007. From human capital to social capital: A longitudinal study of technology-based academic entrepreneurs. Entrepreneurship Theory \& Practice 31, 909-935.

Mueller, S.L., Thomas, A.S., 2001. Culture and entrepreneurial potential: A nine country study of locus of control and innovativeness. Journal of Business Venturing 16, 51-75.

Narayanan, V., Pinches, G., Kelm, K., Lander, D., 2000. The influence of voluntarily disclosed qualitative information. Strategic Management Journal 21, 707-722.

Narula, R., Dunning, J. H., 1998. Explaining international R\&D alliances and the role of governments. International Business Review 7, 377-397.

Nelson, R., 1959. The simple economics of basic scientific research. Journal of Political Economy 67, 297-306.

Nishimura, J., Okamuro, H., 2011. Subsidy and networking: The effects of direct and indirect support programs of the cluster policy. Research Policy 40, 714-727.

Okamuro, H., Kato, M., Honjo Y., 2011. Determinants of R\&D cooperation in Japanese start-ups. Research Policy 40, 728-738.

Okamuro, H., Nishimura, J., 2015. Governance and Performance of Publicly Funded R\&D Consortia (No. 60). Center for Research on Contemporary Economic Systems, Graduate School of Economics, Hitotsubashi University. 
Oxley, J.E., 1997. Appropriability hazards and governance in strategic alliances: a transactions cost approach. Journal of Law Economics and Organization 13, 387-409.

Paeleman, I., Vanacker, T., 2012. The interaction between financial and human resource slack and its effect on firm performance. Frontiers of Entrepreneurship Research 32, 1-16.

Park, S., Zhou, D., 2005. Firm heterogeneity and competitive dynamics in alliance formation. Academy of Management Review 30, 531-554.

Parida, V., Westerberg, M., Frishammar, J., 2012. Inbound open innovation activities in high-tech SMEs: The impact on innovation performance. Journal of Small Business Management 50, 283309.

Peneder, M., 2008. The problem of private under-investment in innovation: A policy mind map. Technovation 28, 518-530.

Pinillos, M-J., Reyes, L., 2011. Relationship between individualist-collectivist culture and entrepreneurial activity: evidence from Global Entrepreneurship Monitor data. Small Business Economics 37, 23-37.

Romijn, H., Albaladejo, M., 2002. Determinants of innovation capability in small electronics and software firms in southeast England. Research Policy 31, 1053-1067.

Rothaermel, F.T., 2001a. Incumbent's advantage through exploiting complementary assets via interfirm cooperation. Strategic Management Journal 22, 687-699.

Rothaermel, F.T., 2001b. Complementary assets, strategic alliances, and the incumbent's advantage: An empirical study of industry and firm effects in the biopharmaceutical industry. Research Policy 30, 1235-1251.

Rothaermel, F.T., 2002. Technological discontinuities and interfirm cooperation: what determines a start-up’s attractiveness as alliance partner?. IEEE Transactions on Engineering Management 49, 388-397.

Samphantharak, K., Malesky, E.J., 2008. Predictable corruption and firm investment: evidence from a natural experiment and survey of Cambodian entrepreneurs. Quarterly Journal of Political Science 3, 227-267.

Santamaría, L., Barge-Gil, A., Modrego, A., 2010. Public selection and financing of R\&D cooperative projects: Credit versus subsidy funding. Research Policy 39, 549-563.

Santarelli, E., Vivarelli, M., 2002. Is subsidizing entry an optimal policy? Industrial and Corporate Change 11, 39-52.

Schein, E.H., 1987. 'Individuals and careers' in J. Lorsch (ed.), Handbook of Organizational Behavior. Englewood Cliffs, NJ: Prentice-Hall, pp. 155-171. 
Shane, S., 2000. Prior knowledge and the discovery of entrepreneurial opportunities. Organization Science 11, 448-469.

Shane, S., 2009. Why encouraging more people to become entrepreneurs is bad public policy. Small Business Economics 33, 141-149.

Shepherd, D.A. DeTienne, D.R., 2005. Prior knowledge, potential financial reward, and opportunity identification. Entrepreneurship Theory \& Practice 29, 91-112.

Stam, E., Wennberg, K., 2009. The roles of R\&D in new firm growth. Small Business Economics 33, 77-89.

Storey, D.J., Tether, B.S., 1998. Public policy measures to support new technology-based firms in the European Union. Research Policy 26, 1037-1057.

Tabellini, G., 2010. Culture and institutions: economic development in the regions of Europe. Journal of the European Economic Association 8, 677-716.

Takalo, T., Tanayama, T., 2010. Adverse selection and financing of innovation: is there a need for R\&D subsidies? Journal of Technology Transfer 35, 16-41.

Takalo, T., Tanayama, T., Toivanen, O., 2013. Estimating the effects of targeted R\&D subsidies. Review of Economics and Statistics 55, 255-272.

Teece, D.J., 1986. Profiting from technological innovation: implications for integration, collaboration, licensing, and public policy. Research Policy 15, 285-305.

Terza, J.V., Basu, A., Rathouz, P.J., 2008. Two-stage residual inclusion estimation: addressing endogeneity in health econometric modeling. Journal of Health Economics 27, 531-543.

Thorgren, S., Wincent J., Boter H., 2012. Small firms in multipartner R\&D alliances: Gaining benefits by acquiescing. Journal of Engineering and Technology Management 29, 453-467.

Timmons, J.A., Spinelli, S., 2003. New Venture Creation: Entrepreneurship for the 21st Century. Boston: McGraw Hill - Irwin.

Wallsten, S.J., 2000.The effects of government-industry R\&D programs on private R\&D: the case of Small Business Innovation Research program. RAND Journal of Economics 31, 82-100.

Whelan, A., McGuinness, S., 2017. Does a satisfied student make a satisfied worker? IZA DP No. 10698.

Wooldridge, J.M., 2010. Econometric Analysis of Cross Section and Panel Data. MIT press.

Zak, P.J., Knack, S., 2001. Trust and growth. Economic Journal 111, 295-321.

Zuniga-Vicente, A.J., Alonso-Borrego, C., Forcadell, F.J., Galàn, J.I., 2014. Assessing the effect of public subsidies on firm R\&D investment: a survey. Journal of Economic Surveys 28, 36-67. 


\section{Tables}

Table I - Definition of variables.

\begin{tabular}{ll}
\hline Variable Definition & D
\end{tabular}

\section{Dependent variables}

R\&D Alliance

Corporate R\&D Alliance

University R\&D Alliance

Selective Subsidy

\section{Founders' technology-related human capital variables}

Technical Education

Industry-Specific Work

Experience

\section{Control variables on} founders' human capital

Economic Education

Management Experience

LogFounders

\section{Exclusion restrictions}

Control versus Fate

Libertarian
Dummy that equals 1 for firms that established an R\&D alliance

Dummy that equals 1 for firms that established a corporate R\&D alliance

Dummy that equals 1 for firms that established an R\&D alliance with an university or a public research organization

Dummy that equals 1 for firms awarded with a selective subsidy before having eventually established an R\&D alliance

Average number of founders' years of scientific and/or technical education at graduate and post-graduate level

Average number of years of founders' work experience in the same industry of the NTBF before NTBF's foundation

Average number of founders' years of economic and/or managerial education at graduate and post-graduate level

Dummy that equals 1 for firms with one or more founders with a prior management position in a company with more than 250 employees or one or more founders with previous entrepreneurial experience

Natural logarithm of the number of founders of the NTBF

Variable computed at the regional NUTS 2 level as answer to the following statement: "Some people feel they have completely free choice and control over their lives, while other people feel that what they do has no real effect on what happens to them. Please use this scale where 1 means "no choice at all" and 10 means "a great deal of choice" to indicate how much freedom of choice and control you feel you have over the way your life turns out” (source: World Values Survey).

Variable computed at the regional NUTS 2 level as answer to the following statement: "Having a strong leader who does not have to bother with parliament and elections" on a 1-4 scale where 1 means "very good" and 4 means "very bad" (source: World Values Survey). 
Table II - Descriptive statistics of explanatory variables and exclusion restrictions.

\begin{tabular}{lllll}
\hline Variable & Mean & S.D. & Min & Max \\
\hline Selective Subsidy & 0.1042 & 0.3057 & 0 & 1 \\
Technical Education & 1.9138 & 2.2514 & 0 & 9 \\
Industry-Specific Work Experience & 4.0021 & 7.0654 & 0 & 37 \\
Economic Education & 0.2851 & 0.8579 & 0 & 5 \\
Management Experience & 0.2251 & 0.4179 & 0 & 1 \\
LogFounders & 1.2885 & 0.3950 & 0.6931 & 3.0910 \\
Control Versus Fate & 6.2973 & 0.3294 & 3 & 7.1333 \\
Libertarian & 3.3410 & 0.1519 & 2.625 & 3.8 \\
\hline \hline
\end{tabular}

Legend: Descriptive statistics based on 902 firms. 
Table III - Correlation matrix.

\begin{tabular}{|c|c|c|c|c|c|c|c|c|c|}
\hline & 1 & 2 & 3 & 4 & 5 & 6 & 7 & 8 & 9 \\
\hline 1. R\&D Alliance & 1 & & & & & & & & \\
\hline 2. Corporate R\&D Alliance & $0.8336 *$ & 1 & & & & & & & \\
\hline 3. University R\&D Alliance & $0.5531 *$ & $0.2066^{*}$ & 1 & & & & & & \\
\hline 4. Selective Subsidy & $0.1085 *$ & 0.0152 & $0.1705^{*}$ & 1 & & & & & \\
\hline 5. Technical Education & 0.1219* & 0.0213 & $0.2227^{*}$ & $0.0918^{*}$ & 1 & & & & \\
\hline $\begin{array}{l}\text { 6. Industry-Specific Work } \\
\text { Experience }\end{array}$ & -0.0484 & -0.0177 & -0.0621 & -0.0070 & -0.0368 & 1 & & & \\
\hline 7. Economic Education & $0.0906^{*}$ & $0.1143^{*}$ & -0.0215 & 0.0136 & $-0.1252 *$ & $-0.0899 *$ & 1 & & \\
\hline 8. Management Experience & -0.0101 & 0.0152 & -0.0181 & -0.0274 & 0.0063 & $0.2472 *$ & 0.0342 & 1 & \\
\hline 9. LogFounders & $0.1264 *$ & $0.0881 *$ & $0.1547^{*}$ & 0.0239 & $0.1759 *$ & -0.0023 & 0.0061 & $0.0922 *$ & 1 \\
\hline
\end{tabular}


Table IV - Selective subsidies and R\&D alliances.

\begin{tabular}{|c|c|c|c|c|c|c|c|c|c|c|}
\hline & \multicolumn{3}{|c|}{ R\&D Alliance } & & \multicolumn{2}{|c|}{ Corporate R\&D Alliance } & \multirow[b]{2}{*}{ Total } & \multicolumn{2}{|c|}{ University R\&D Alliance } & \multirow[b]{2}{*}{ Total } \\
\hline & Value & 0 & 1 & Total & 0 & 1 & & 0 & 1 & \\
\hline \multirow{2}{*}{$\begin{array}{l}\text { Selective } \\
\text { Subsidy }\end{array}$} & 0 & 469 (52.00\%) & 339 (37.58\%) & 808 (89.58\%) & 467 (56.88\%) & 281 (34.23\%) & 748 (91.11\%) & $468(68.72 \%)$ & 138 (20.26\%) & 606 (88.99\%) \\
\hline & 1 & 38 (4.21\%) & 56 (6.21\%) & 94 (10.42\%) & 38 (4.63\%) & 35 (4.26\%) & 73 (8.89\%) & 38 (5.58\%) & 37 (5.43\%) & 75 (11.01\%) \\
\hline Total & & 507 (56.21\%) & 395 (43.79\%) & 902 (100\%) & 505 (61.51\%) & 316 (38.49\%) & 821 (100\%) & 506 (74.30\%) & 175 (25.70\%) & 681 (100\%) \\
\hline
\end{tabular}

Legend: The total number of firms is 902. As to the corporate and university R\&D alliances, the total number of firms is 821 and 681 , respectively. This is due to the fact that we built the two variables

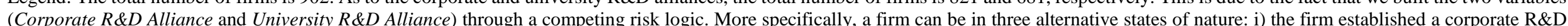

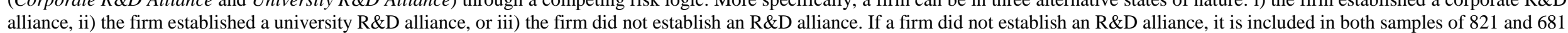
firms. If a firm established a corporate $R \& D$ alliance at year $t$ and an $R \& D$ alliance with an academic partner at year $t+1$, this firm is only included in the sample of 821 firms. Conversely, if a firm established a university R\&D alliance at year $t$ and an $R \& D$ alliance with a corporate partner at year $t+1$, this firm is only included in the sample of 681 firms. 
Table V - ML recursive bivariate probit results.

\begin{tabular}{|c|c|c|c|}
\hline & Column I & Column II & Column III \\
\hline \multicolumn{4}{|l|}{ Panel A. Dependent Variable: Selective Subsidy } \\
\hline \multirow[t]{2}{*}{ Technical Education } & $0.0568 * *$ & 0.0442 & 0.0364 \\
\hline & $(0.0256)$ & $(0.0280)$ & $(0.0294)$ \\
\hline \multirow[t]{2}{*}{ Industry-Specific Work Experience } & 0.0028 & -0.0024 & -0.0050 \\
\hline & $(0.0089)$ & $(0.0098)$ & $(0.0103)$ \\
\hline \multirow[t]{2}{*}{ Economic Education } & 0.0652 & 0.0179 & 0.0893 \\
\hline & $(0.0682)$ & $(0.0762)$ & $(0.0834)$ \\
\hline \multirow[t]{2}{*}{ Management Experience } & -0.2061 & -0.1063 & -0.0990 \\
\hline & $(0.1519)$ & $(0.1604)$ & $(0.1677)$ \\
\hline \multirow[t]{2}{*}{ LogFounders } & 0.0024 & -0.0858 & 0.0136 \\
\hline & $(0.1496)$ & $(0.1669)$ & $(0.1678)$ \\
\hline \multirow[t]{2}{*}{ Control versus Fate } & $-0.6468 * * *$ & $-0.6446 * * *$ & $-0.6242 * * *$ \\
\hline & $(0.1516)$ & $(0.1573)$ & $(0.1711)$ \\
\hline \multirow[t]{2}{*}{ Libertarian } & $1.1481^{* * *}$ & $1.0697 * * *$ & $1.0520 * * *$ \\
\hline & $(0.3577)$ & $(0.3867)$ & $(0.4050)$ \\
\hline \multirow[t]{2}{*}{ Constant } & -1.2904 & -0.9540 & -1.0362 \\
\hline & $(1.3570)$ & $(1.4304)$ & $(1.5844)$ \\
\hline Industry dummies & Yes & Yes & Yes \\
\hline Panel B. Dependent Variable: R\&D Alliance & R\&D Alliance & $\begin{array}{r}\text { Corporate R\&D } \\
\text { Alliance }\end{array}$ & $\begin{array}{r}\text { University } \\
\text { R\&D Alliance }\end{array}$ \\
\hline \multirow[t]{2}{*}{ Selective Subsidy } & $1.1042^{* *}$ & $1.1133^{* *}$ & $1.3716^{* * *}$ \\
\hline & $(0.5565)$ & $(0.5646)$ & $(0.4916)$ \\
\hline \multirow[t]{2}{*}{ Technical Education } & $0.0592 * * *$ & $0.0386 *$ & $0.1166^{* * *}$ \\
\hline & $(0.0214)$ & $(0.0219)$ & $(0.0250)$ \\
\hline \multirow[t]{2}{*}{ Industry-Specific Work Experience } & -0.0030 & 0.0023 & -0.0105 \\
\hline & $(0.0064)$ & $(0.0067)$ & $(0.0084)$ \\
\hline \multirow[t]{2}{*}{ Economic Education } & $0.1307^{* *}$ & $0.1494 * * *$ & 0.0564 \\
\hline & $(0.0516)$ & $(0.0516)$ & $(0.0727)$ \\
\hline \multirow[t]{2}{*}{ Management Experience } & -0.0160 & 0.0008 & -0.0683 \\
\hline & $(0.1062)$ & (0.1098) & $(0.1355)$ \\
\hline \multirow[t]{2}{*}{ LogFounders } & $0.3502 * * *$ & $0.3481 * * *$ & $0.4907 * * *$ \\
\hline & $(0.1111)$ & $(0.1163)$ & (0.1378) \\
\hline \multirow[t]{2}{*}{ Constant } & $-0.7824^{* * *}$ & $-0.8470 * * *$ & $-1.6847 * * *$ \\
\hline & $(0.1530)$ & $(0.1615)$ & $(0.1976)$ \\
\hline Industry dummies & Yes & Yes & Yes \\
\hline LR $($ rho $=0)$ & $1.2787[1]$ & $1.6979[1]$ & $1.5754[1]$ \\
\hline Obs. & 902 & 821 & 681 \\
\hline
\end{tabular}

Legend: * p-value $<0.1 ; * *$ p-value $<0.05 ; * * *$ p-value $<0.01$. Standard errors in round brackets. Degrees of freedom in square brackets. Industry dummies are included in the estimates (the coefficients are omitted in the table). 
Table VI - Standard 2SLS results.

\begin{tabular}{lrrr}
\hline & Column I & Column II & Column III \\
\hline Dependent Variable: R\&D Alliance & R\&D Alliance & $\begin{array}{r}\text { Corporate } \\
\text { R\&D Alliance }\end{array}$ & $\begin{array}{r}\text { University } \\
\text { R\&D Alliance }\end{array}$ \\
\hline Selective Subsidy & $0.5330^{*}$ & $0.6870^{*}$ & $1.0151^{* * *}$ \\
& $(0.3126)$ & $(0.3705)$ & $(0.3668)$ \\
Technical Education & $0.0219^{* * *}$ & 0.0125 & $0.0330^{* * *}$ \\
& $(0.0084)$ & $(0.0089)$ & $(0.0089)$ \\
Industry-Specific Work Experience & -0.0011 & 0.0011 & -0.0020 \\
Economic Education & $(0.0025)$ & $(0.0027)$ & $(0.0028)$ \\
& $0.0500^{* *}$ & $0.0584^{* * *}$ & 0.0050 \\
Management Experience & $(0.0200)$ & $(0.0206)$ & $(0.0256)$ \\
& -0.0025 & 0.0019 & -0.0145 \\
LogFounders & $(0.0418)$ & $(0.0434)$ & $(0.0457)$ \\
Constant & $0.1371 * * *$ & $0.1363^{* * *}$ & $0.1485^{* * *}$ \\
& $(0.0430)$ & $(0.0461)$ & $(0.0475)$ \\
Industry dummies & $0.1861^{* * *}$ & $0.1502^{* *}$ & -0.0963 \\
$\mathrm{R}^{2}$ & $(0.0625)$ & $(0.0693)$ & $(0.0695)$ \\
F test on excluded instruments & Yes & Yes & Yes \\
Anderson LM statistic & 0.4377 & 0.3399 & 0.1117 \\
Sargan test & $14.00^{* * *[2,891]}$ & $11.76^{* * *}[2$, & $8.88^{* * *[2,670]}$ \\
Obs. & & $810]$ & $17.591^{* * *[2]}$ \\
\hline \hline
\end{tabular}

Legend: * p-value $<0.1 ; * *$ p-value $<0.05 ; * * *$ p-value $<0.01$. Standard errors in round brackets. Degrees of freedom in square brackets. Industry dummies are included in the estimates (the coefficients are omitted in the table). 
Table VII - “Special regressor” results.

\begin{tabular}{lrrr}
\hline & Column I & Column II & Column III \\
\hline Dependent Variable: R\&D Alliance & R\&D Alliance & $\begin{array}{r}\text { Corporate R\&D } \\
\text { Alliance }\end{array}$ & $\begin{array}{r}\text { University R\&D } \\
\text { Alliance }\end{array}$ \\
\hline Selective Subsidy & $0.3921^{* *}$ & $0.6870^{* * *}$ & 0.3848 \\
& $(0.1964)$ & $(0.2544)$ & $(0.2370)$ \\
Special Regressor & $0.0018^{* * *}$ & $0.0016^{* *}$ & $0.0013^{*}$ \\
& $(0.0006)$ & $(0.0007)$ & $(0.0007)$ \\
Obs. & 902 & 821 & 681 \\
\hline \hline
\end{tabular}

Legend: * p-value $<0.1 ; * *$ p-value $<0.05 ; * * *$ p-value $<0.01$. Standard errors in round brackets. The variable Special Regressor is the regional average bank branch density in 1936 - as measured by the values of bank branches per inhabitant. Technical Education, Industry-Specific Work Experience, Economic Education, Management Experience, LogFounders, industry dummies and the constant are included in the estimates (the coefficients are omitted in the table). 


\section{Figures}

Figure I - Justification of the semiparametric "special regressor".

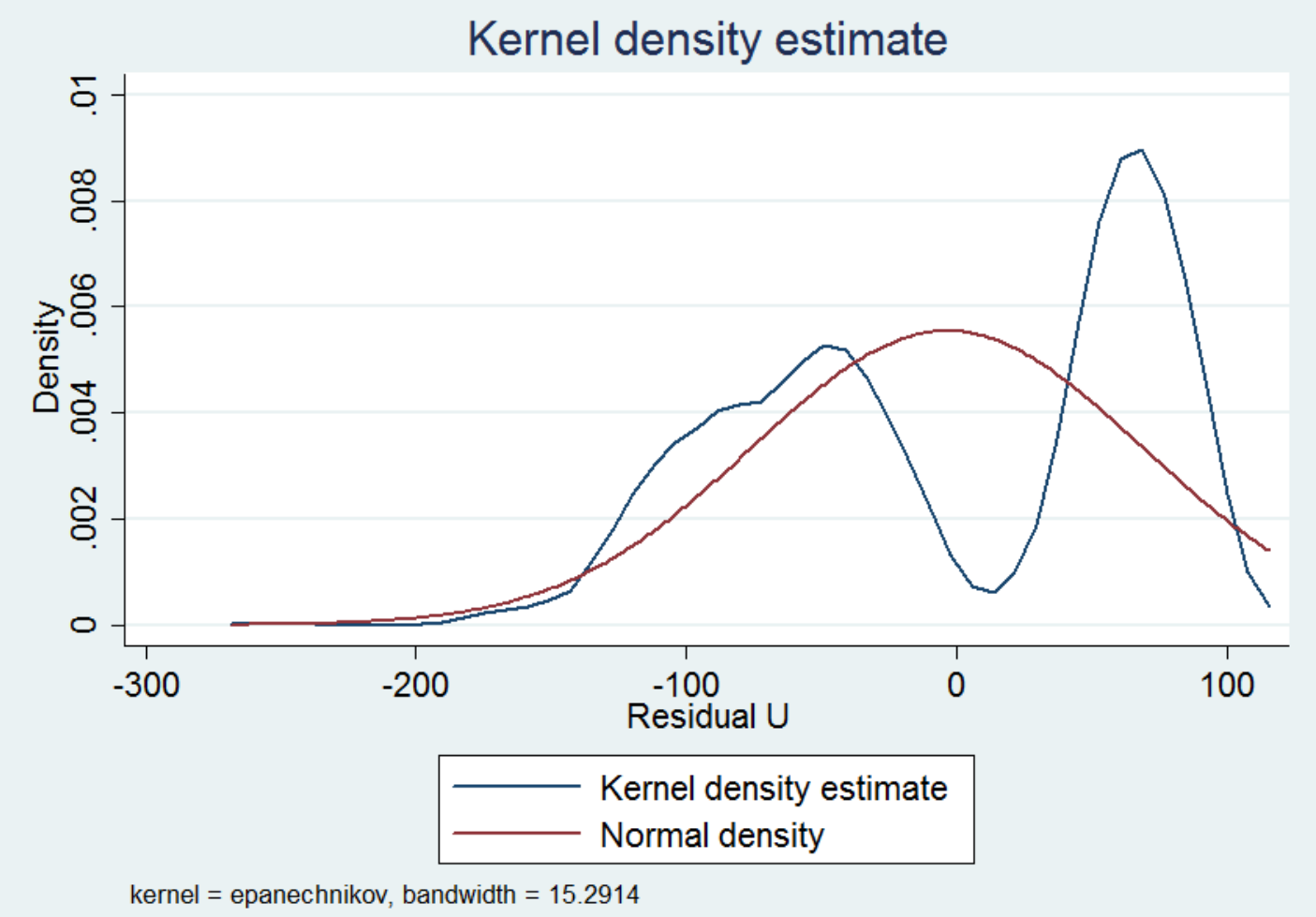


Figure II - Graphical test of hypothesis 3: estimated probability

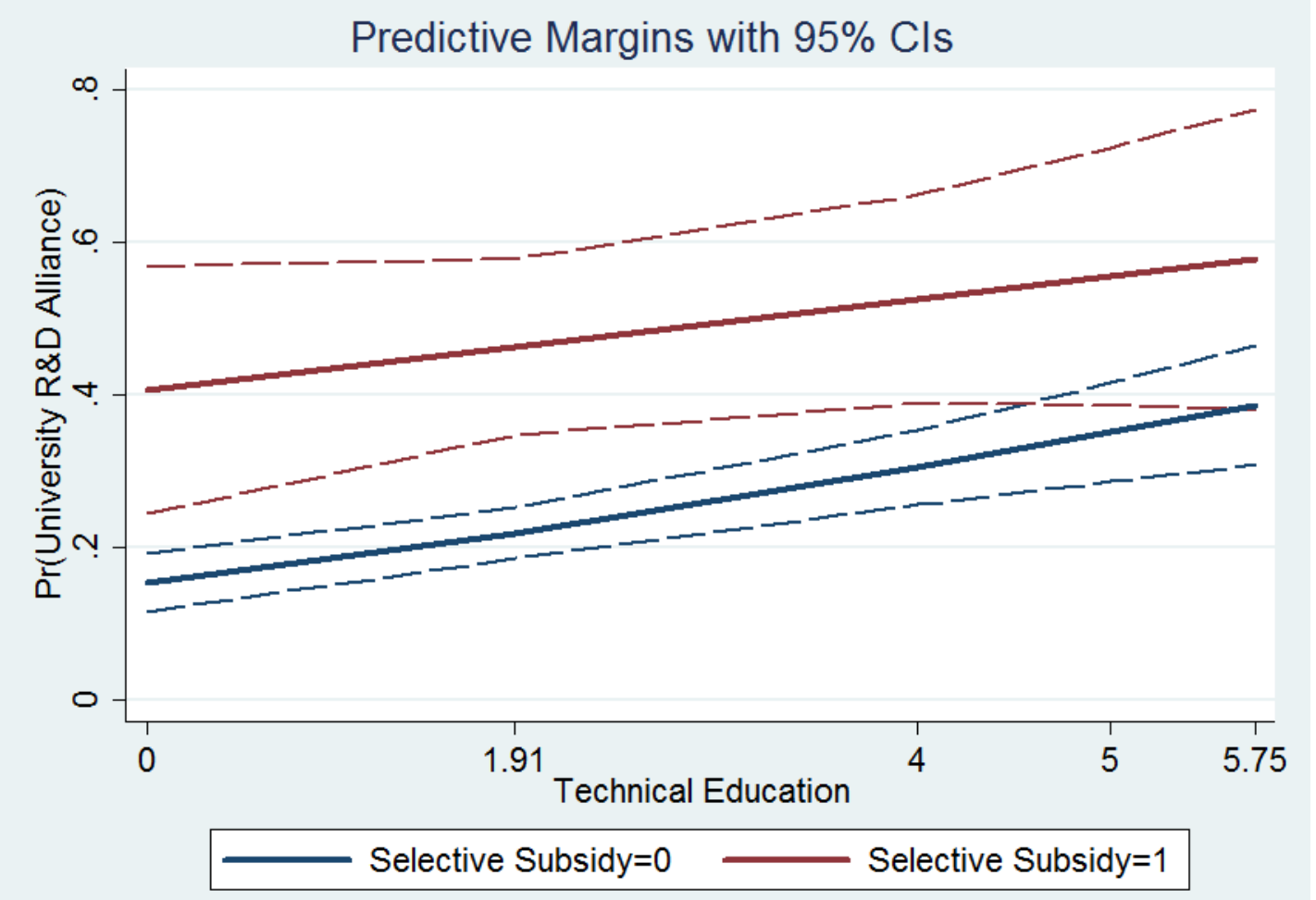


Figure III - Graphical test of hypothesis 3: marginal effects of the interaction term Selective Subsidy $\times$ Technical Education

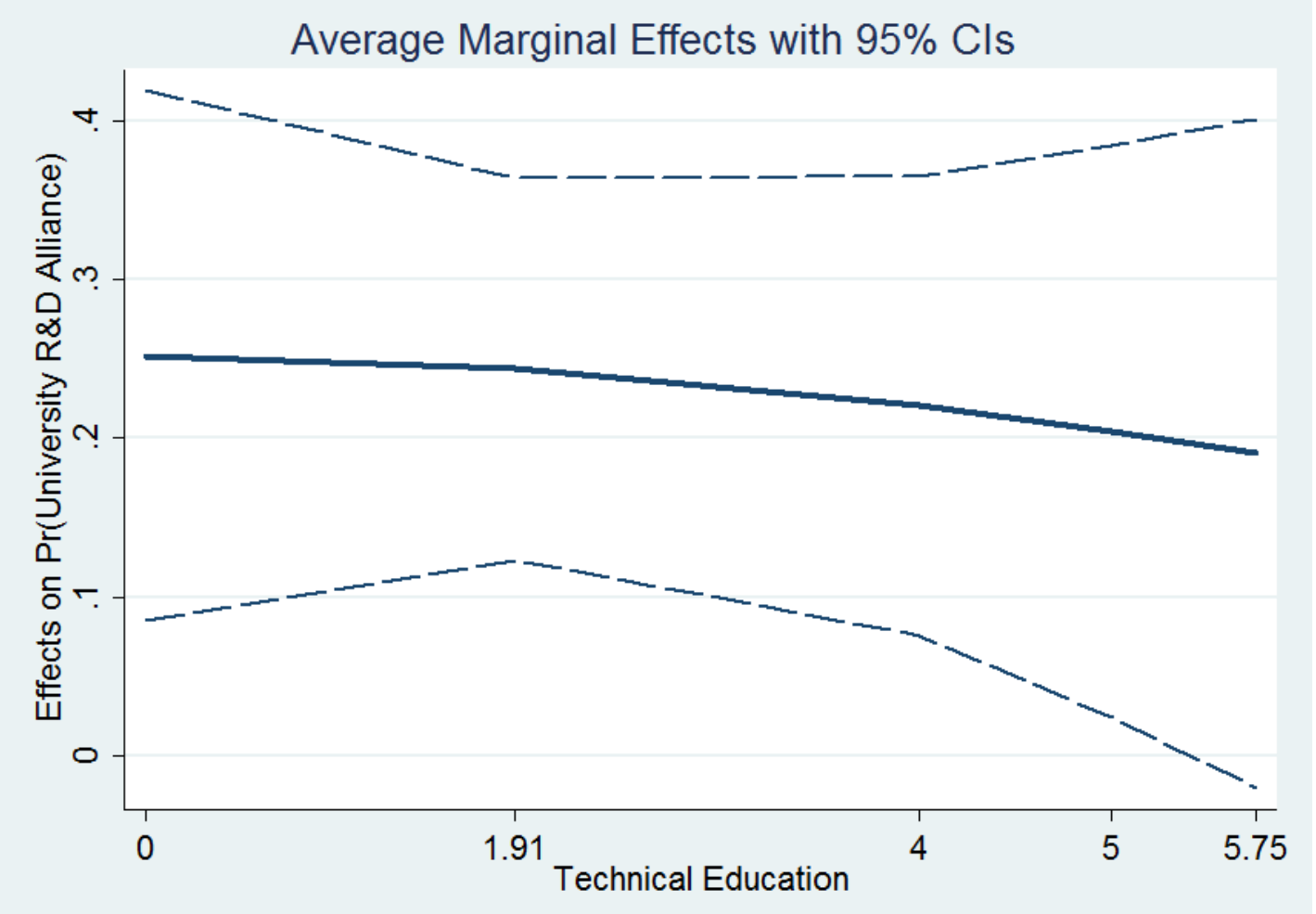


Figure IV - Graphical test of hypothesis 4: estimated probability

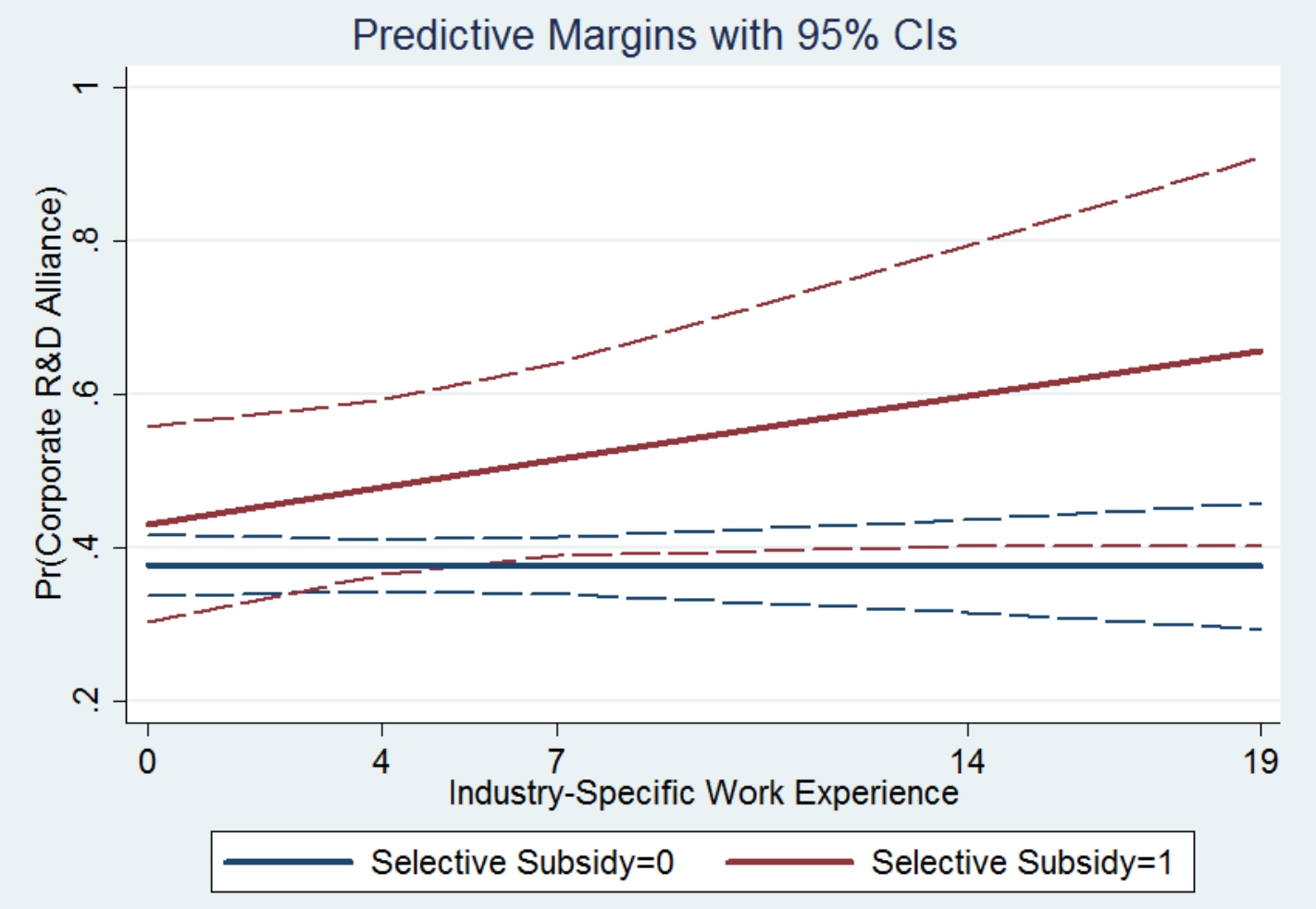


Figure V - Graphical test of hypothesis 4: marginal effects of the interaction term Selective Subsidy $\times$ Industry-specific work experience

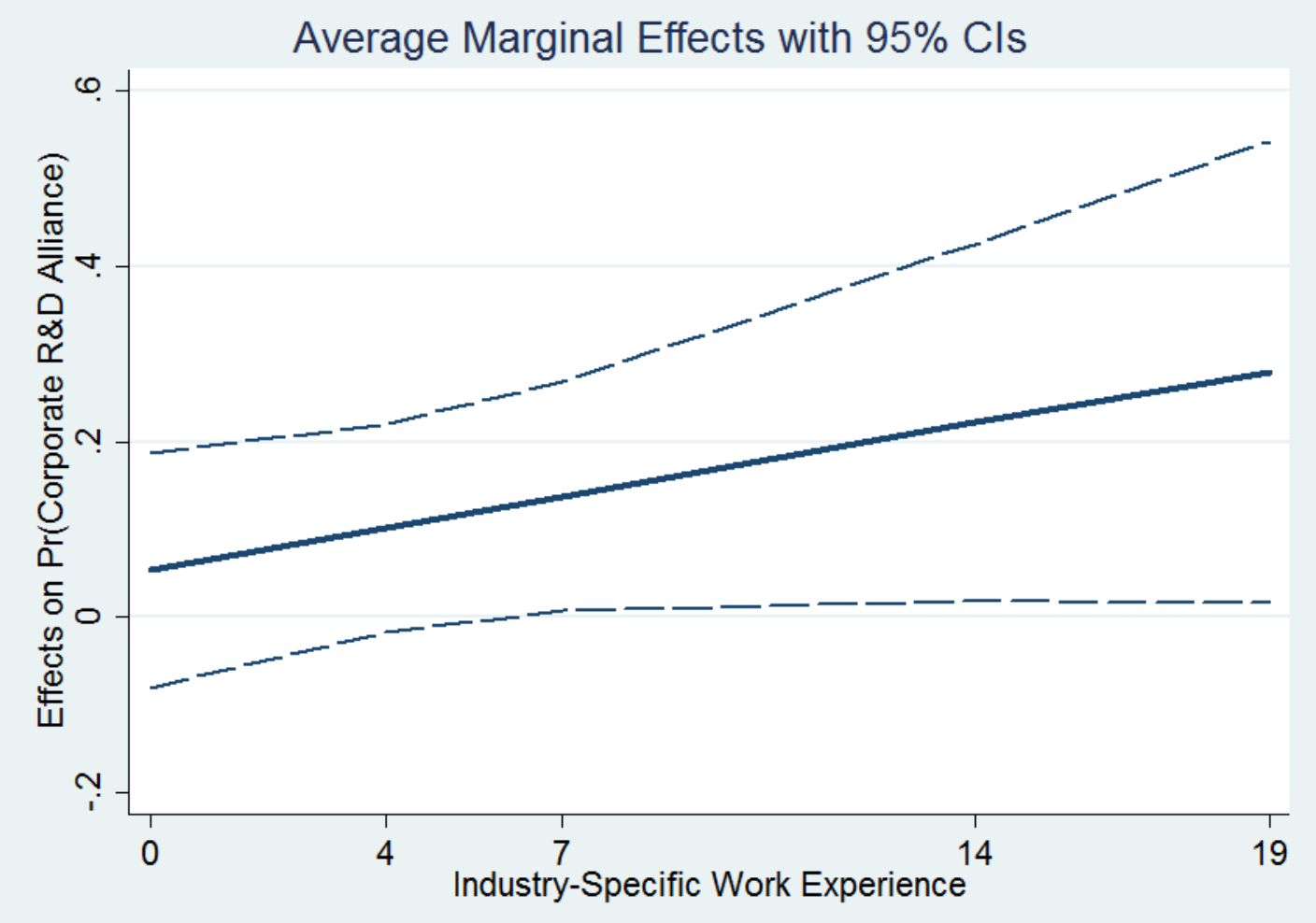




\section{Appendix}

Table A1 - ML recursive bivariate probit results.

\begin{tabular}{|c|c|c|c|}
\hline & Column I & Column II & Column III \\
\hline \multicolumn{4}{|l|}{ Panel A. Dependent Variable: Selective Subsidy } \\
\hline Technical Education & $\begin{array}{r}0.0549 * * \\
(0.0257)\end{array}$ & $\begin{array}{r}0.0406 \\
(0.0282)\end{array}$ & $\begin{array}{r}0.0323 \\
(0.0296)\end{array}$ \\
\hline Industry-Specific Work Experience & $\begin{array}{r}0.0025 \\
(0.0090)\end{array}$ & $\begin{array}{r}-0.0025 \\
(0.0099)\end{array}$ & $\begin{array}{r}-0.0055 \\
(0.0104)\end{array}$ \\
\hline Economic Education & $\begin{array}{r}0.0598 \\
(0.0686)\end{array}$ & $\begin{array}{r}0.0089 \\
(0.0772)\end{array}$ & $\begin{array}{r}0.0799 \\
(0.0841)\end{array}$ \\
\hline Management Experience & $\begin{array}{r}-0.2121 \\
(0.1525)\end{array}$ & $\begin{array}{r}-0.1182 \\
(0.1615)\end{array}$ & $\begin{array}{r}-0.1085 \\
(0.1683)\end{array}$ \\
\hline LogFounders & $\begin{array}{r}0.0075 \\
(0.1494)\end{array}$ & $\begin{array}{r}-0.0726 \\
(0.1665)\end{array}$ & $\begin{array}{r}0.0201 \\
(0.1673)\end{array}$ \\
\hline General Trust & $\begin{array}{r}-0.6009 \\
(0.4825)\end{array}$ & $\begin{array}{r}-0.8662 * \\
(0.5235)\end{array}$ & $\begin{array}{r}-0.6352 \\
(0.5376)\end{array}$ \\
\hline Control versus Fate & $\begin{array}{r}-0.6916 * * * \\
(0.1545)\end{array}$ & $\begin{array}{r}-0.7127 * * * \\
(0.1624)\end{array}$ & $\begin{array}{r}-0.6663 * * * \\
(0.1726)\end{array}$ \\
\hline Libertarian & $\begin{array}{r}1.2809 * * * \\
(0.3737)\end{array}$ & $\begin{array}{r}1.2645^{* * * *} \\
(0.4089)\end{array}$ & $\begin{array}{r}1.2019 * * * \\
(0.4236)\end{array}$ \\
\hline Constant & $\begin{array}{r}-0.5438 \\
(1.4769)\end{array}$ & $\begin{array}{r}0.1292 \\
(1.5633)\end{array}$ & $\begin{array}{r}-0.3090 \\
(1.6874)\end{array}$ \\
\hline Industry dummies & Yes & Yes & Yes \\
\hline Panel B. Dependent Variable: R\&D Alliance & R\&D Alliance & $\begin{array}{r}\text { Corporate } \mathbf{R} \& \mathbf{D} \\
\text { Alliance } \\
\end{array}$ & $\begin{array}{r}\text { University } \\
\text { R\&D Alliance } \\
\end{array}$ \\
\hline Selective Subsidy & $\begin{array}{r}1.1308 * * \\
(0.5340)\end{array}$ & $\begin{array}{r}1.0918^{* *} \\
(0.5473)\end{array}$ & $\begin{array}{r}1.4208^{* * *} \\
(0.4678)\end{array}$ \\
\hline Technical Education & $\begin{array}{r}0.0587 * * * \\
(0.0213)\end{array}$ & $\begin{array}{l}0.0389 * \\
(0.0218)\end{array}$ & $\begin{array}{r}0.1152^{* * * *} \\
(0.0251)\end{array}$ \\
\hline Industry-Specific Work Experience & $\begin{array}{r}-0.0031 \\
(0.0065)\end{array}$ & $\begin{array}{r}0.0023 \\
(0.0067)\end{array}$ & $\begin{array}{r}-0.0106 \\
(0.0084)\end{array}$ \\
\hline Economic Education & $\begin{array}{r}0.1296 * * \\
(0.0516)\end{array}$ & $\begin{array}{r}0.1499 * * * \\
(0.0517)\end{array}$ & $\begin{array}{r}0.0536 \\
(0.0727)\end{array}$ \\
\hline Management Experience & $\begin{array}{r}-0.0143 \\
(0.1061)\end{array}$ & $\begin{array}{r}0.0006 \\
(0.1099)\end{array}$ & $\begin{array}{r}-0.0676 \\
(0.1353)\end{array}$ \\
\hline LogFounders & $\begin{array}{r}0.3495^{* * * *} \\
(0.1110)\end{array}$ & $\begin{array}{r}0.3481^{* * *} \\
(0.1163)\end{array}$ & $\begin{array}{r}0.4875 * * * \\
(0.1377)\end{array}$ \\
\hline General Trust & $\begin{array}{r}-0.0845 \\
(0.3489)\end{array}$ & $\begin{array}{r}0.0669 \\
(0.3664)\end{array}$ & $\begin{array}{r}-0.1242 \\
(0.4338)\end{array}$ \\
\hline Constant & $\begin{array}{r}-0.6543 \\
(0.5516)\end{array}$ & $\begin{array}{r}-0.9481 \\
(0.5797)\end{array}$ & $\begin{array}{r}-1.4921^{* *} \\
(0.6937)\end{array}$ \\
\hline Industry dummies & Yes & Yes & Yes \\
\hline LR $($ rho $=0)$ & $1.4814[1]$ & $1.7827[1]$ & $1.9433[1]$ \\
\hline Obs. & 902 & 821 & 681 \\
\hline
\end{tabular}

Legend: * p-value $<0.1 ; * *$ p-value $<0.05 ; * * *$ p-value $<0.01$. Standard errors in round brackets. Degrees of freedom in square brackets. Industry dummies are included in the estimates (the coefficients are omitted in the table). 
Table A2 - Standard 2SLS results.

\begin{tabular}{|c|c|c|c|}
\hline & Column I & Column II & Column III \\
\hline \multicolumn{4}{|l|}{ Panel A. Dependent Variable: Selective Subsidy } \\
\hline \multirow[t]{2}{*}{ Technical Education } & $0.0105 * *$ & 0.0072 & 0.0070 \\
\hline & $(0.0046)$ & $(0.0046)$ & $(0.0055)$ \\
\hline \multirow[t]{2}{*}{ Industry-Specific Work Experience } & 0.0002 & -0.0005 & -0.0010 \\
\hline & $(0.0015)$ & $(0.0015)$ & $(0.0018)$ \\
\hline \multirow[t]{2}{*}{ Economic Education } & 0.0107 & 0.0015 & 0.0147 \\
\hline & $(0.0119)$ & $(0.0114)$ & $(0.0161)$ \\
\hline \multirow[t]{2}{*}{ Management Experience } & -0.0325 & -0.0157 & -0.0163 \\
\hline & $(0.0250)$ & $(0.0242)$ & $(0.0297)$ \\
\hline \multirow[t]{2}{*}{ LogFounders } & -0.0016 & -0.0144 & 0.0023 \\
\hline & $(0.0261)$ & $(0.0257)$ & $(0.0307)$ \\
\hline \multirow[t]{2}{*}{ General Trust } & -0.1114 & $-0.1578 *$ & -0.1118 \\
\hline & $(0.0863)$ & $(0.0850)$ & $(0.1018)$ \\
\hline \multirow[t]{2}{*}{ Control versus Fate } & $-0.1622 * * *$ & $-0.1582 * * *$ & $-0.1481^{* * *}$ \\
\hline & $(0.0324)$ & $(0.0321)$ & $(0.0377)$ \\
\hline \multirow[t]{2}{*}{ Libertarian } & $0.2306 * * *$ & $0.1919 * * *$ & $0.2243^{* * *}$ \\
\hline & $(0.0691)$ & $(0.0675)$ & $(0.0827)$ \\
\hline \multirow[t]{2}{*}{ Constant } & 0.4912 & $0.6805^{* *}$ & 0.4309 \\
\hline & $(0.3028)$ & $(0.2998)$ & $(0.3560)$ \\
\hline Industry dummies & Yes & Yes & Yes \\
\hline Panel B. Dependent Variable: R\&D Alliance & R\&D Alliance & $\begin{array}{r}\text { Corporate } \\
\text { R\&D Alliance }\end{array}$ & $\begin{array}{r}\text { University } \\
\text { R\&D Alliance }\end{array}$ \\
\hline \multirow[t]{2}{*}{ Selective Subsidy } & $0.5566 *$ & $0.6649^{*}$ & $1.0605^{* * *}$ \\
\hline & $(0.3050)$ & $(0.3452)$ & $(0.3605)$ \\
\hline \multirow[t]{2}{*}{ Technical Education } & $0.0216^{* *}$ & 0.0127 & $0.0324 * * *$ \\
\hline & $(0.0084)$ & $(0.0088)$ & $(0.0090)$ \\
\hline \multirow[t]{2}{*}{ Industry-Specific Work Experience } & -0.0012 & 0.0011 & -0.0020 \\
\hline & $(0.0025)$ & $(0.0027)$ & $(0.0028)$ \\
\hline \multirow[t]{2}{*}{ Economic Education } & $0.0496 * *$ & $0.0586 * * *$ & 0.0035 \\
\hline & $(0.0201)$ & $(0.0205)$ & $(0.0260)$ \\
\hline \multirow[t]{2}{*}{ Management Experience } & -0.0018 & 0.0017 & -0.0144 \\
\hline & $(0.0419)$ & $(0.0432)$ & $(0.0464)$ \\
\hline \multirow[t]{2}{*}{ LogFounders } & $0.1369 * * *$ & $0.1360 * * *$ & $0.1480 * * *$ \\
\hline & $(0.0431)$ & $(0.0460)$ & $(0.0482)$ \\
\hline \multirow[t]{2}{*}{ General Trust } & -0.0361 & 0.0312 & -0.0566 \\
\hline & $(0.1378)$ & $(0.1453)$ & $(0.1533)$ \\
\hline \multirow[t]{2}{*}{ Constant } & 0.2395 & 0.1046 & -0.0129 \\
\hline & $(0.2181)$ & $(0.2325)$ & $(0.2438)$ \\
\hline Industry dummies & Yes & Yes & Yes \\
\hline $\mathrm{R}^{2}$ & 0.4339 & 0.3452 & 0.0845 \\
\hline F test on excluded instruments & $14.82 * * *[2,890]$ & $13.48 * * *[2,809]$ & $\begin{array}{r}9.48 * * *[2, \\
669]\end{array}$ \\
\hline Anderson LM statistic & $29.065 * * *[2]$ & $26.476 * * *[2]$ & $18.769 * * *[2]$ \\
\hline Sargan test & $1.724[1]$ & $1.198[1]$ & $1.811[1]$ \\
\hline Obs. & 902 & 821 & 681 \\
\hline
\end{tabular}

Legend: * p-value $<0.1 ; * *$ p-value $<0.05 ; * * *$ p-value $<0.01$. Standard errors in round brackets. Degrees of freedom in square brackets. Industry dummies are included in the estimates (the coefficients are omitted in the table). 
Table A3 - 2SRI results.

\begin{tabular}{|c|c|c|c|}
\hline & Column I & Column II & Column III \\
\hline Dependent Variable: R\&D Alliance & R\&D Alliance & $\begin{array}{r}\text { Corporate R\&D } \\
\text { Alliance } \\
\end{array}$ & $\begin{array}{r}\text { University R\&D } \\
\text { Alliance }\end{array}$ \\
\hline Selective Subsidy & $\begin{array}{r}0.2563 * * \\
(0.1246)\end{array}$ & $\begin{array}{r}0.1535^{*} \\
(0.0802)\end{array}$ & $\begin{array}{r}0.3924^{* *} \\
(0.1550)\end{array}$ \\
\hline Technical Education & $\begin{array}{r}0.0686 * * * \\
(0.0215)\end{array}$ & $\begin{array}{r}0.0461 \\
(0.0318)\end{array}$ & $\begin{array}{r}0.1271^{* * * *} \\
(0.0252)\end{array}$ \\
\hline Industry-Specific Work Experience & $\begin{array}{r}-0.0029 \\
(0.0102)\end{array}$ & $\begin{array}{r}0.0026 \\
(0.0089)\end{array}$ & $\begin{array}{r}-0.0105 \\
(0.0065)\end{array}$ \\
\hline Economic Education & $\begin{array}{r}0.1442 * * * \\
(0.0501)\end{array}$ & $\begin{array}{r}0.1579 * * \\
(0.0662)\end{array}$ & $\begin{array}{r}0.0743 \\
(0.0531)\end{array}$ \\
\hline Management Experience & $\begin{array}{r}-0.0393 \\
(0.1251)\end{array}$ & $\begin{array}{r}-0.0174 \\
(0.0948)\end{array}$ & $\begin{array}{r}-0.1016 \\
(0.3330)\end{array}$ \\
\hline LogFounders & $\begin{array}{r}0.3388 * * * \\
(0.1010)\end{array}$ & $\begin{array}{r}0.3252 * * * \\
(0.0714)\end{array}$ & $\begin{array}{r}0.4702 * * * \\
(0.1622)\end{array}$ \\
\hline Control versus Fate & $\begin{array}{r}-0.0800 \\
(0.1296)\end{array}$ & $\begin{array}{r}-0.1733 \\
(0.1236)\end{array}$ & $\begin{array}{r}-0.2597 \\
(0.2899)\end{array}$ \\
\hline Libertarian & $\begin{array}{r}0.5273 \\
(0.4138)\end{array}$ & $\begin{array}{r}0.5638 \\
(0.3984)\end{array}$ & $\begin{array}{r}0.9804 \\
(0.6568)\end{array}$ \\
\hline First-stage Residual & $\begin{array}{r}0.0608 \\
(0.0652)\end{array}$ & $\begin{array}{r}0.0337 \\
(0.0982)\end{array}$ & $\begin{array}{r}0.1088 \\
(0.0990)\end{array}$ \\
\hline Constant & $\begin{array}{r}-1.9520 \\
(1.1932)\end{array}$ & $\begin{array}{r}-1.5457 * \\
(0.9066)\end{array}$ & $\begin{array}{r}-3.2277 \\
(2.2584)\end{array}$ \\
\hline $\begin{array}{l}\text { Industry dummies } \\
\text { Obs. }\end{array}$ & $\begin{array}{l}\text { Yes } \\
902\end{array}$ & $\begin{array}{l}\text { Yes } \\
821\end{array}$ & $\begin{array}{l}\text { Yes } \\
681\end{array}$ \\
\hline
\end{tabular}

Legend: * p-value $<0.1 ; * *$ p-value $<0.05 ; * * *$ p-value $<0.01$. Bootstrapped standard errors in round brackets. Degrees of freedom in square brackets. Industry dummies are included in the estimates (the coefficients are omitted in the table). 
Table A4 - ML recursive bivariate probit results.

\begin{tabular}{|c|c|c|c|}
\hline & Column I & Column II & Column III \\
\hline \multicolumn{4}{|l|}{ Panel A. Dependent Variable: Selective Subsidy } \\
\hline Technical Education & $\begin{array}{r}0.0532 * * \\
(0.0259)\end{array}$ & $\begin{array}{r}0.0382 \\
(0.0285)\end{array}$ & $\begin{array}{r}0.0344 \\
(0.0297)\end{array}$ \\
\hline Industry-Specific Work Experience & $\begin{array}{r}-0.0005 \\
(0.0095)\end{array}$ & $\begin{array}{r}-0.0078 \\
(0.0109)\end{array}$ & $\begin{array}{r}-0.0101 \\
(0.0113)\end{array}$ \\
\hline Economic Education & $\begin{array}{r}0.0756 \\
(0.0686)\end{array}$ & $\begin{array}{r}0.0275 \\
(0.0766)\end{array}$ & $\begin{array}{r}0.1013 \\
(0.0847)\end{array}$ \\
\hline Management Experience & $\begin{array}{r}-0.2125 \\
(0.1543)\end{array}$ & $\begin{array}{r}-0.1030 \\
(0.1637)\end{array}$ & $\begin{array}{r}-0.1283 \\
(0.1708)\end{array}$ \\
\hline LogFounders & $\begin{array}{r}-0.0075 \\
(0.1508)\end{array}$ & $\begin{array}{r}-0.0985 \\
(0.1688)\end{array}$ & $\begin{array}{r}-0.0081 \\
(0.1691)\end{array}$ \\
\hline Control versus Fate & $\begin{array}{r}-0.4461^{* *} \\
(0.1939)\end{array}$ & $\begin{array}{r}-0.4165^{* *} \\
(0.2063)\end{array}$ & $\begin{array}{r}-0.4954^{* *} \\
(0.1949)\end{array}$ \\
\hline Libertarian & $\begin{array}{r}1.2816 * * * \\
(0.3798)\end{array}$ & $\begin{array}{r}1.2634 * * * \\
(0.4218)\end{array}$ & $\begin{array}{r}1.1139 * * * \\
(0.4273)\end{array}$ \\
\hline Special Regressor & $\begin{array}{r}-0.0004 \\
(0.0008)\end{array}$ & $\begin{array}{r}-0.0003 \\
(0.0009)\end{array}$ & $\begin{array}{r}-0.0005 \\
(0.0009)\end{array}$ \\
\hline Constant & $\begin{array}{l}-2.9179 * \\
(1.7416)\end{array}$ & $\begin{array}{r}-2.9564 \\
(1.9380)\end{array}$ & $\begin{array}{r}-1.9333 \\
(1.8373)\end{array}$ \\
\hline Industry dummies & Yes & Yes & Yes \\
\hline Panel B. Dependent Variable: R\&D Alliance & R\&D Alliance & $\begin{array}{r}\text { Corporate R\&D } \\
\text { Alliance }\end{array}$ & $\begin{array}{r}\text { University } \\
\text { R\&D Alliance }\end{array}$ \\
\hline Selective Subsidy & $\begin{array}{l}1.1839 * \\
(0.6163)\end{array}$ & $\begin{array}{r}1.0842 \\
(0.6850)\end{array}$ & $\begin{array}{r}1.3057 * * \\
(0.5435)\end{array}$ \\
\hline Technical Education & $\begin{array}{r}0.0612 * * * \\
(0.0220)\end{array}$ & $\begin{array}{l}0.0436 * \\
(0.0222)\end{array}$ & $\begin{array}{r}0.1180 * * * \\
(0.0253)\end{array}$ \\
\hline Industry-Specific Work Experience & $\begin{array}{r}-0.0011 \\
(0.0066)\end{array}$ & $\begin{array}{r}0.0047 \\
(0.0069)\end{array}$ & $\begin{array}{r}-0.0092 \\
(0.0087)\end{array}$ \\
\hline Economic Education & $\begin{array}{r}0.1429 * * * \\
(0.0532)\end{array}$ & $\begin{array}{r}0.1656 * * * \\
(0.0530)\end{array}$ & $\begin{array}{r}0.0646 \\
(0.0743)\end{array}$ \\
\hline Management Experience & $\begin{array}{r}0.0029 \\
(0.1075)\end{array}$ & $\begin{array}{r}0.0147 \\
(0.1108)\end{array}$ & $\begin{array}{r}-0.0625 \\
(0.1371)\end{array}$ \\
\hline LogFounders & $\begin{array}{r}0.3416 * * * \\
(0.1119)\end{array}$ & $\begin{array}{r}0.3464 * * * \\
(0.1170)\end{array}$ & $\begin{array}{r}0.4797^{* * *} \\
(0.1380)\end{array}$ \\
\hline Constant & $\begin{array}{r}-0.7999 * * * \\
(0.1540)\end{array}$ & $\begin{array}{r}-0.8747 * * * \\
(0.1636)\end{array}$ & $\begin{array}{r}-1.6685^{* * *} \\
(0.1985)\end{array}$ \\
\hline Industry dummies & Yes & Yes & Yes \\
\hline LR $($ rho $=0)$ & $1.4814[1]$ & $1.7827[1]$ & $1.9433[1]$ \\
\hline Obs. & 886 & 806 & 672 \\
\hline
\end{tabular}

Legend: * p-value $<0.1 ; * *$ p-value $<0.05$; *** p-value $<0.01$. Standard errors in round brackets. Degrees of freedom in square brackets. Industry dummies are included in the estimates (the coefficients are omitted in the table). Data on Special Regressor are not available for the regions Valle d'Aosta and Molise. 
Table A5 - Standard 2SLS results.

\begin{tabular}{|c|c|c|c|}
\hline & Column I & Column II & Column III \\
\hline Dependent Variable: R\&D Alliance & R\&D Alliance & $\begin{array}{r}\text { Corporate R\&D } \\
\text { Alliance } \\
\end{array}$ & $\begin{array}{r}\text { University R\&D } \\
\text { Alliance }\end{array}$ \\
\hline Selective Subsidy & $\begin{array}{c}0.7582 * \\
(0.3915)\end{array}$ & $\begin{array}{c}0.9898 * \\
(0.5121)\end{array}$ & $\begin{array}{r}1.1947 * * * \\
(0.4428)\end{array}$ \\
\hline Technical Education & $\begin{array}{r}0.0209 * * \\
(0.0090)\end{array}$ & $\begin{array}{r}0.0124 \\
(0.0097)\end{array}$ & $\begin{array}{r}0.0321^{* * * *} \\
(0.0096)\end{array}$ \\
\hline Industry-Specific Work Experience & $\begin{array}{r}-0.0001 \\
(0.0027)\end{array}$ & $\begin{array}{r}0.0028 \\
(0.0030)\end{array}$ & $\begin{array}{r}-0.0008 \\
(0.0031)\end{array}$ \\
\hline Economic Education & $\begin{array}{r}0.0523 * * \\
(0.0213)\end{array}$ & $\begin{array}{r}0.0632 * * * \\
(0.0223)\end{array}$ & $\begin{array}{r}0.0025 \\
(0.0283)\end{array}$ \\
\hline Management Experience & $\begin{array}{r}0.0107 \\
(0.0446)\end{array}$ & $\begin{array}{r}0.0110 \\
(0.0468)\end{array}$ & $\begin{array}{r}-0.0050 \\
(0.0495)\end{array}$ \\
\hline LogFounders & $\begin{array}{r}0.1336 * * * \\
(0.0449)\end{array}$ & $\begin{array}{r}0.1384 * * * \\
(0.0495)\end{array}$ & $\begin{array}{r}0.1460 * * * \\
(0.0506)\end{array}$ \\
\hline Constant & $\begin{array}{r}0.1647 * * \\
(0.0672)\end{array}$ & $\begin{array}{r}0.1142 \\
(0.0794)\end{array}$ & $\begin{array}{r}-0.1101 \\
(0.0771)\end{array}$ \\
\hline Industry dummies & Yes & Yes & Yes \\
\hline $\mathrm{R}^{2}$ & 0.3896 & 0.2447 & 0.0028 \\
\hline F test on excluded instruments & $6.50 * * *[3,874]$ & $4.76 * * *[3,794]$ & $4.62 * * *[3,660]$ \\
\hline Anderson LM statistic & $19.336 * * *[3]$ & $14.235 * * *[3]$ & $13.829 * * *[3]$ \\
\hline Sargan test & $2.490[2]$ & $1.231[2]$ & $3.000[2]$ \\
\hline t statistic on Special Regressor & -0.40 & -0.42 & -0.35 \\
\hline Obs. & 886 & 806 & 672 \\
\hline
\end{tabular}

Legend: * p-value $<0.1 ; * *$ p-value $<0.05 ; * * *$ p-value $<0.01$. Standard errors in round brackets. Degrees of freedom in square brackets. Industry dummies are included in the estimates (the coefficients are omitted in the table). Data on Special Regressor are not available for the regions Valle d'Aosta and Molise. 
Table A6 - IV probit results.

\begin{tabular}{lrr}
\hline & Column I & Column II \\
\hline Dependent Variable: R\&D Alliance & Corporate & University \\
R\&D & R\&D \\
Alliance
\end{tabular}

Legend: * p-value $<0.1 ; * *$ p-value $<0.05$; *** p-value $<0.01$. Standard errors in round brackets. Degrees of freedom in square brackets. Industry dummies are included in the estimates (the coefficients are omitted in the table). The variable Selective Subsidy and its interaction terms with Technical Education and Industry-specific work experience have been instrumented with the predicted value of Selective Subsidy (by means of a linear probability model) and its interactions with Technical Education and Industry-specific work experience. 